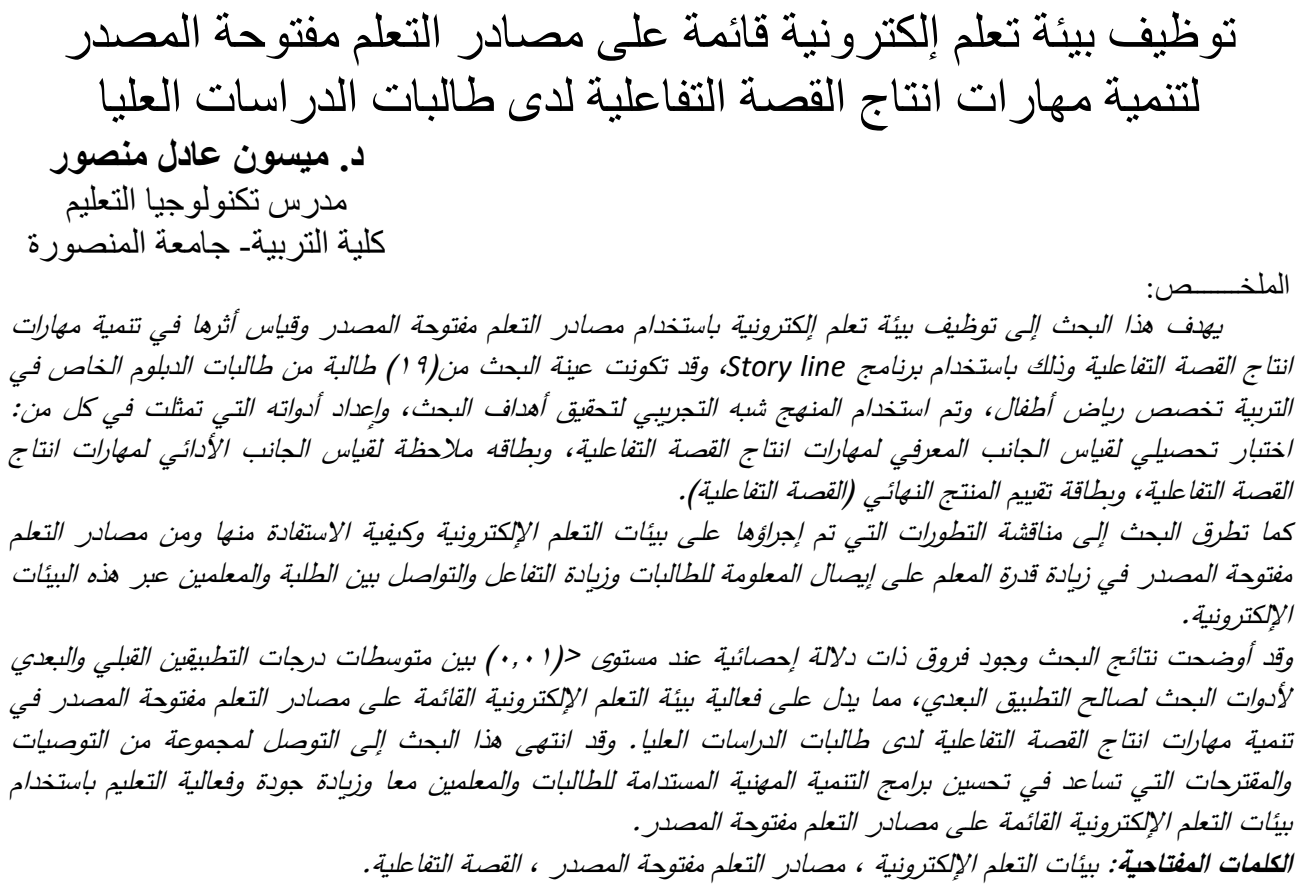

Abstract:

This study aims at employing an electronic learning environment using open learning resources and measuring its impact on developing the skills of Implementing interactive story using Story line. The sample consisted of (19) students among special diploma in kindergartens, Semi Experimental approach was used To achieve the study objectives ,and to prepare its tools that were represented in the following: Achievement test to measure the cognitive side of Implementing interactive story skills and observation card to measure the performance side of Implementing interactive story skills , and the final product evaluation card (interactive story).The study also discussed the procedures of developing e-learning environments and how to benefit from them and from the open learning resources in increasing the teacher's ability to interact and communicate with students through these electronic environments. The results of the study showed that there were statistically significant differences at level (0.01) between the mean scores of the pre and post assessment of the research tools in favor of the post assessment. This indicates the effectiveness of the e-learning environment based on the open learning resource on developing implementing interactive story skills among the graduate students. This study has resulted in a set of recommendations and proposals that help improve sustainable professional development programs for students and teachers together and increase the quality and effectiveness of education using e-learning environments based on open learning resources.

$$
\begin{aligned}
& \text { المعلم وتخريج أفراد قادرين علي مواكبة التقدم } \\
& \text { العلمي والتكنولوجي، ومواجهة متطلبات الحياة } \\
& \text { المعاصـرة وتطورها من أجل تحقيق تعلم أكثر } \\
& \text { فاعلية وكفاءة. } \\
& \text { ونظـراً للتغير المستمر والتطور الحـادث } \\
& \text { في مستحدثات تكنولوجيـا التعليم، فقد تـأثرت }
\end{aligned}
$$

$$
\begin{aligned}
& \text { يثـهد عالمنـا اليـوم ثـورة تكنولوجيـة في } \\
& \text { شتى مجالات الحياة، انطلقت من ظهور العديد } \\
& \text { من المستحدثات التكنولوجية متلاحقة في فترة } \\
& \text { زمنيـة قصسيرة، وأمـام كل هذا كـان لزامـاً على } \\
& \text { المؤسسـات التعليميـة إعـادة النظر في تطوير }
\end{aligned}
$$


المعلمين من تقويم المتعلمين بسهولة، وتعد من أهم التقنيات الحديثة التي يمكن توظيفها داخل

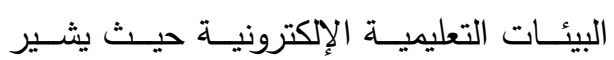
"هيرنانديــــهـ ســيرانو"(2009،Hernandes) علي ضرورة تضمين بيئات التعلم القائمة علي الويـــب أدوات تتــيح المشــــاركة والتفاعـــلـ الاجتماعي بين الأفراد، وأشار إلي الكثير من

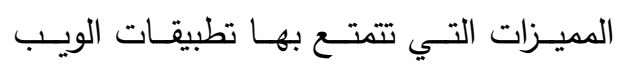
التفاعليـة، حيــث أنهـا تسـاعد المتعلمـين فـي ليـي تطوير بيئات التعلم الخاصــة بهم، إلي جانب أنها تقوم علي الذكاء الاجتمـاعي، نظـراً لأن النمـو المتزايــد لمسـتخدمي الويـبـ والثـبكات الاجتماعية ارتبط بالذكاء الاجتماعي، كما أنها تحقق نوعـاً متقدماً مسن التفاعل، سـواء أكـان الاه

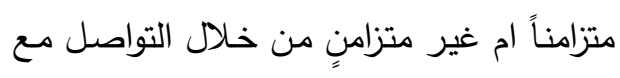

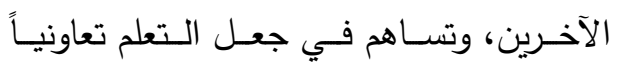
وتكاملياً بـين الطالبـات، فـالجميع يتشـارك في التحرير والنشر والإضـافة والتعليق، كما تؤدي إلي المساهمة الفعالة من قبل المستخدم، والتي تسهم بدورها في التعلم الذاتي، فهي قائمـة علي

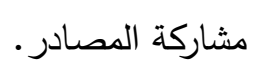
ويضيف أكرم على (11) أن بيئات التعلم الإكترونية تعتمد في الأساس على دعم الاتصال والثراكة بين المتعلمين، والتعاون بينهم في بناء مجتمعات إلكترونية، تعتمد فيها استراتيجية التعلم على التكامل بين كل عناصر

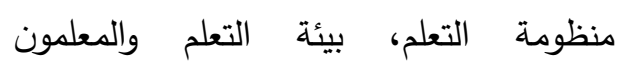

عمليتي التعليم والتعلم بذلك، فظهرت الكثير من المستحدثات التكنولوجية، والتي من أهمها بيئات التعلم الإلكترونية التي تتيح المشاركات

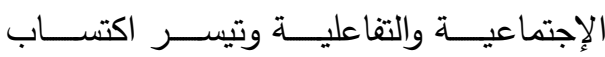
المهارات، الأمـر الذي أدي أيضـاً إلـي ظهور اتجاهات واهتمامـات بحثية وتطويريـة تستهدف توظيف وتصميم تلك البيئات وخاصـة في ظل وجود مصادر التعلم مفتوحة المصدر وفاعليتها في أداء مهمات تعلم/ تدريب متتوعة ومتغيرات تصميم مختلفة لدي العديد من المتعلمين. ولكي يـتم ذلك بشكل صـحيح لابـد من تـوفير بيئـات تعليميـة تواكـب تلـك التطـورات والمســتحدثات، وتعدـلـل علـي تحقيـق هــــه الأهداف المنشودة بشكل جيد، وتعتبر البيئات التعليمية الإلكترونية من أهم تلك المستحدثات التي طرأت علي العملية التعليمية، نظراً لكونها

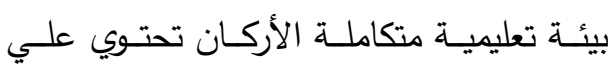
النصـوص والصـور ولقطـات الفيديو والصـوت بداخل نظـام واحد فقط، بالإضـافة إلي إمكانية التعامـل مـن خلالهـا مـع كم ضــخم مـن قواعد البيانات وتقدم تفاعلات سهلة ومرنة نسبياً بين المتعلم والتكنولوجيا المقدمة له من خلالها. (Caplow \& Julie 2006) كما أنها تعمل علي توظيف تكنولوجيا

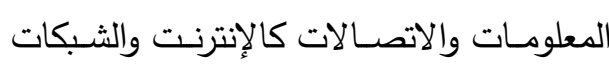
داخلهـا، وذلك لـدعم التفاعل المتزامن وغيـر المتزامن بين المعلمين والمتعلمين بصورة تمكن ودن 
والبرمجيـات، حيــث أنهـــا تمكـن الطالبــات

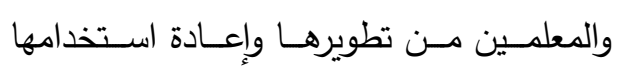
وتوظيفها في مواقف جديدة. وهذا ما أكد عليه كلاً من "يوكونج ولي" هولئ

أن F. (2011)، Y.\& Lei،Yueqing الغرض مـن استخدام مصـادر التعلم مفتوحـة المصدر هو توفير الوصول المفتوح إلي مواد

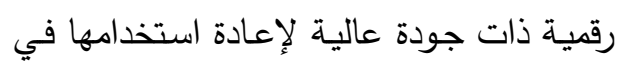
مواقف تعلم جديدة، ويوصسي بتحسين نوعيـة

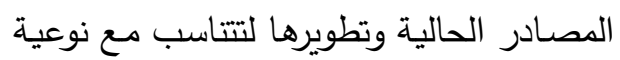
السياقات التربويـة المختلفـة، وتعزيـز اسـتخدام مصـادر التعلم مفتوحسة المصـدر في بيئـات التعلم الإكتروني أيضاً.

حيـث تتميـز مصــادر الـتعلم مفتوحسـة المصدر علي اختلاف أنواعها وتصنيفاتها أنها ذات جـودة عاليـة، وسـريعة التطـوير ، وأكثر

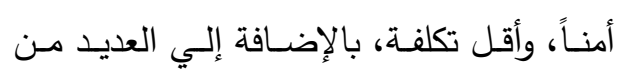

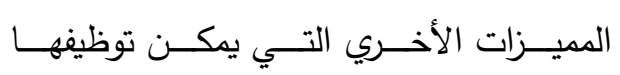
والاستفادة منها في إنتاج القصة التفاعلية.

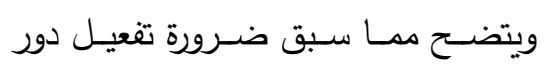

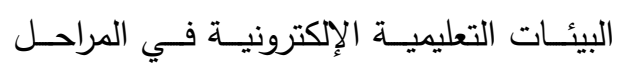

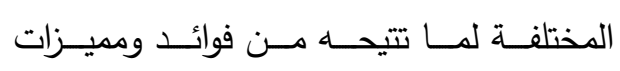

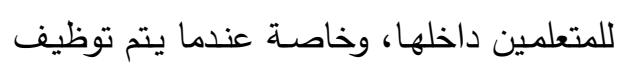
مصادر التعلم مفتوحة المصدر لما توفره للبيئة

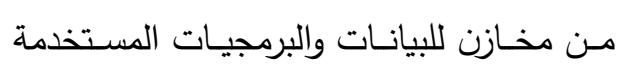
بكافة أنواعها، وكذلك توفير المعالجات القويـة

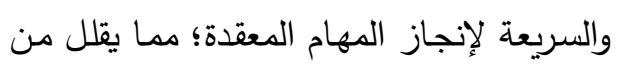

$$
\text { والمتعلمون. }
$$

مما سبق يتضح مدي أهمية بيئات التعلم

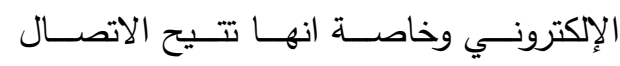

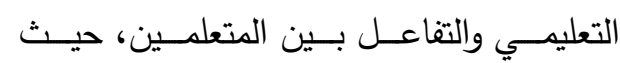

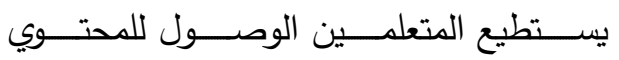

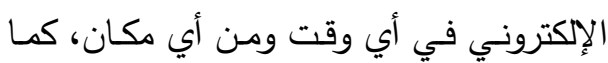

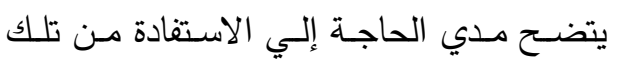
البيئات الإككترونيـة في التعليم والتدريب، لذا لذا لإنية اهتم البحث الحالي بتصميم بيئة تعلم إلكترونية

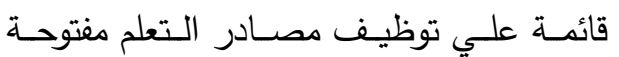
المصدر لتنمية مهارات انتاج القصة التفاعلية.

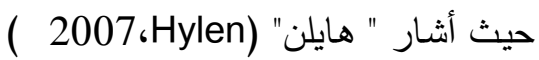

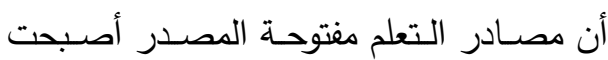
من أهم التقنيات الحديثة التي ينبغي توظيفها خاصة مع التطور السريع للإنترنت، وهذا يحتم

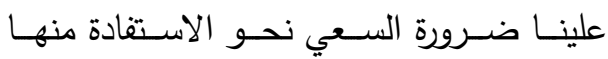

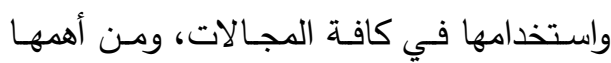
المجال التعليمي، فهذه المصـادر تساعد علي

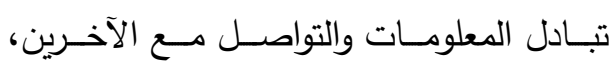

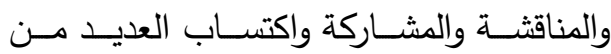
المهارات بين المتعلمين. وأوضح إبراهيم عبد الفتاح يونس( ( . . ب) أن مصـادر التعلم مفتوحـة المصسر تعد أحد اليد

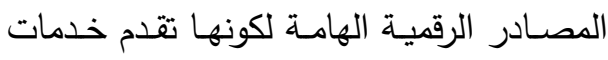
موجهة للتعليم والتدريب، إلي جانب أنها تسهح في حل الكثير من الإثكاليات التي يعاني منها

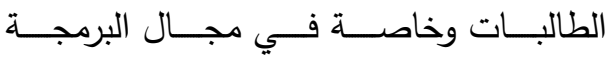


وقــــ أوجـــ التطـور السـريع فـي وسـائل الإعلام الإككترونية ووسائل التكنولوجيا الأخرى خلال السنوات القليلة الماضية تزايد في الطلب الإلب

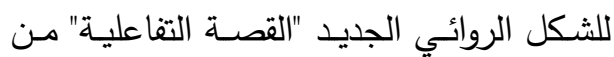

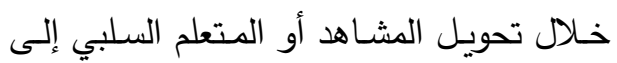
مساهم ومتفاعل مع القصة المعروضة أمامه. تحديد مشكلة البحث:

تحددت مشكلة البحث من خلال مقابلة الباحثة

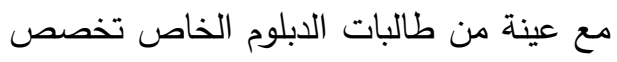
رياض أطفال اتضح وجود مشكلات تتعلق بمهارات تصميم وإنتاج القصة التفاعلية المرتبطة بموضوعات مقرر تكنولوجيا التعليم في مرحلة الطفولة نظرا لعدم وجود جانب عملي وتطبيقي يقوم الطالبات بتتفيذه وذلك لطيك نظرا" لضيق الوقت المخصص للتعلم والتدريب، وعدم وجود التدريب العملي على تلك المهارات، وعدم توفر ساعات كافية في وجي

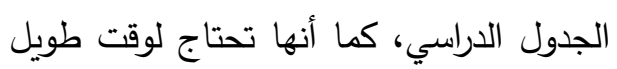
حتى تتدرب الطالبات عليها ومدى أهميتها في توصيل المفاهيم والمهارات والاجتماعية والقيم الأخلاقية لأطفال ماقبل المدرسة وهذا ما أكدته دراسة ميسون

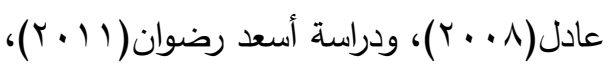

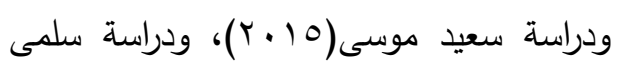

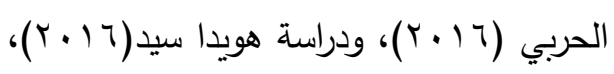
مما يتطلب توظيف بيئات التعلم الإلكترونية القائمة على مصادر التعلم مفتوحة المصدر لئطر
تكلفــة الأجهـزة والبرمجيـات وأمـاكن التخـزين

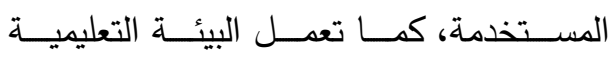
الإلكترونيـة إلي توفير مجموعـة مـن مصـادر

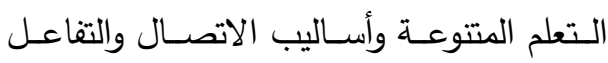
المختلفة بين الطالبات وبعضهـم وبينهم وبين المعلمين، و توفير بيئة تعليمية مشوقة وجذابة

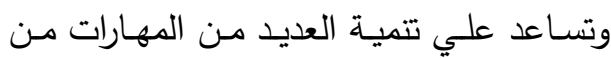

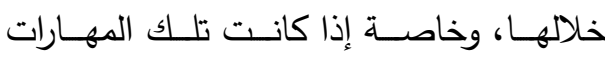

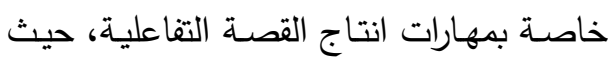
تعـد مهـارات انتـاج القصــة التقاعليـة مـن أهم المهارات التي تحتاجها طالبات رياض أطفال،

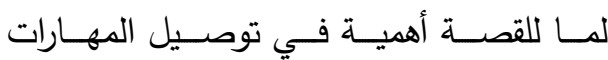
الاجتماعيـة والحياتيـة للأطفـال بصـورة مشـوقة توصة وممتعة. كما أن استخدام الأسلوب القصصي في

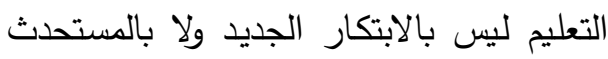

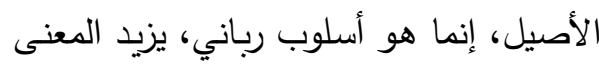

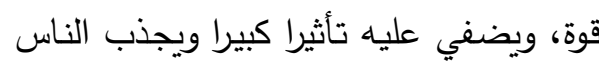

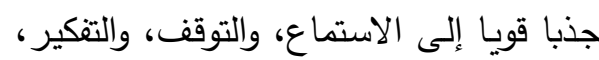
والتأمل .كما ونجد المصطفى صلى الله عليه

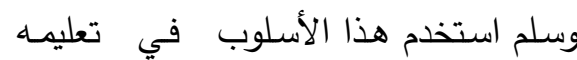

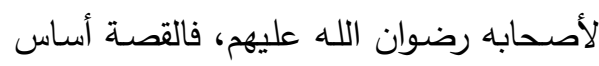
تربوي يمكن الاعتماد عليه في تحسين القدرات، واذا مـا دمجنا التربية الإسلامية

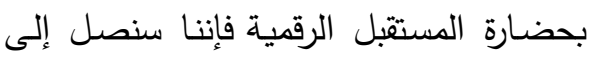

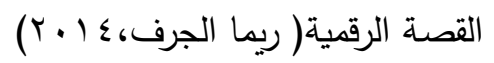


ع- ما فاعلية بيئة التعلم الإكتروني القائمة

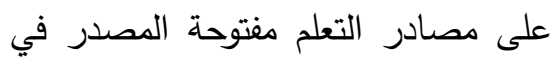
تتمية الجوانب الأدائية لمهارات إنتاج القصة التفاعلية لدى طالبات الدراسات العليا ؟ ؟- ما فاعلية بيئة التعلم الإلكتروني القائمة على مصادر التعلم مفتوحة المصدر على لئل جودة إنتاج القصة التفاعلية لدى طالبات

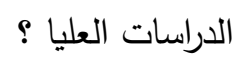$$
\text { أهداف البحث: }
$$

يسعى البحث الحالي إلى تحقيق الأهداف التالية: 1 - إعداد قائمة بمهارات إنتاج القصة التفاعلية الواجب توافرها لدى طالبات الدراسات العليا بكلية التربية. ץ- وضع التصميم التعليمي مقترح لبيئة التعلم الإكتروني القائمة على مصادر التعلم مفتوحة المصدر لتتمية مهارات إنتاج القصة التفاعلية

لدى طالبات الدراسات العليا بكلية التربية.

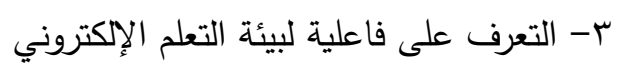

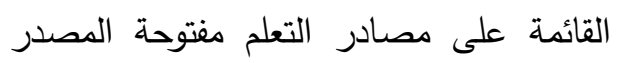

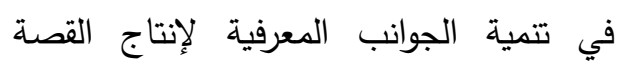
التفاعلية لدى طالبات الدراسات العليا بكلية التربية. ع- التعرف على فاعلية لبيئة التعلم الإككتروني القائمة على مصادر التعلم مفتوحة المصدر لتعر لإلئه

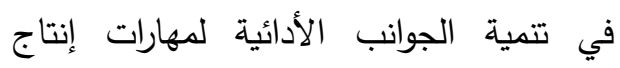

لتوصيل المحتوى التعليمي للطالبات وتنمية مهارات انتاج القصة التفاعلية لديهن. في ضوء ما سبق يمكن صياغة مشكلة البحث

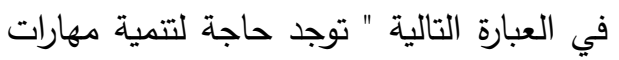
إنتاج القصة التفاعلية لدى طالبات الدراسات العليا بكلية التربية باستخدام بيئة تعلم إلكترونية قائمة على مصادر التعلم مفتوحة المصدر" ولذا يتطلب البحث الحالي الاجابة عن السؤال الرئيسي التالي: ما أثر توظيف بيئة تعلم إلكترونية قائمة على لتى مصادر التعلم مفتوحة المصدر لتنمية مهارات إنتاج القصة التفاعلية لاى طالبات الدراسات العليا ؟ ويتڤرع من هذا التساؤل الرئيسي الأسئلة الفرعية التالية : 1- ما مهارات إنتاج القصة التفاعلية الواجب

$$
\text { توافرها لدى طالبات الدراسات العليا ؟ }
$$

ץ- ما التصميم التعليمي المقترح لبيئة التعلم

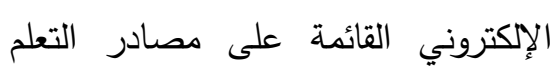
مفتوحة المصدر لتتمية مهارات إنتاج القصة التفاعلية لدى طالبات الدراسات العليا ؟ r- ما فاعلية بيئة التعلم الإكتروني القائمة على مصادر التعلم مفتوحة المصدر في تتمية الجوانب المعرفية لإنتاج القصة لهوديه التفاعلية لاى طالبات الدراسات العليا ؟ 


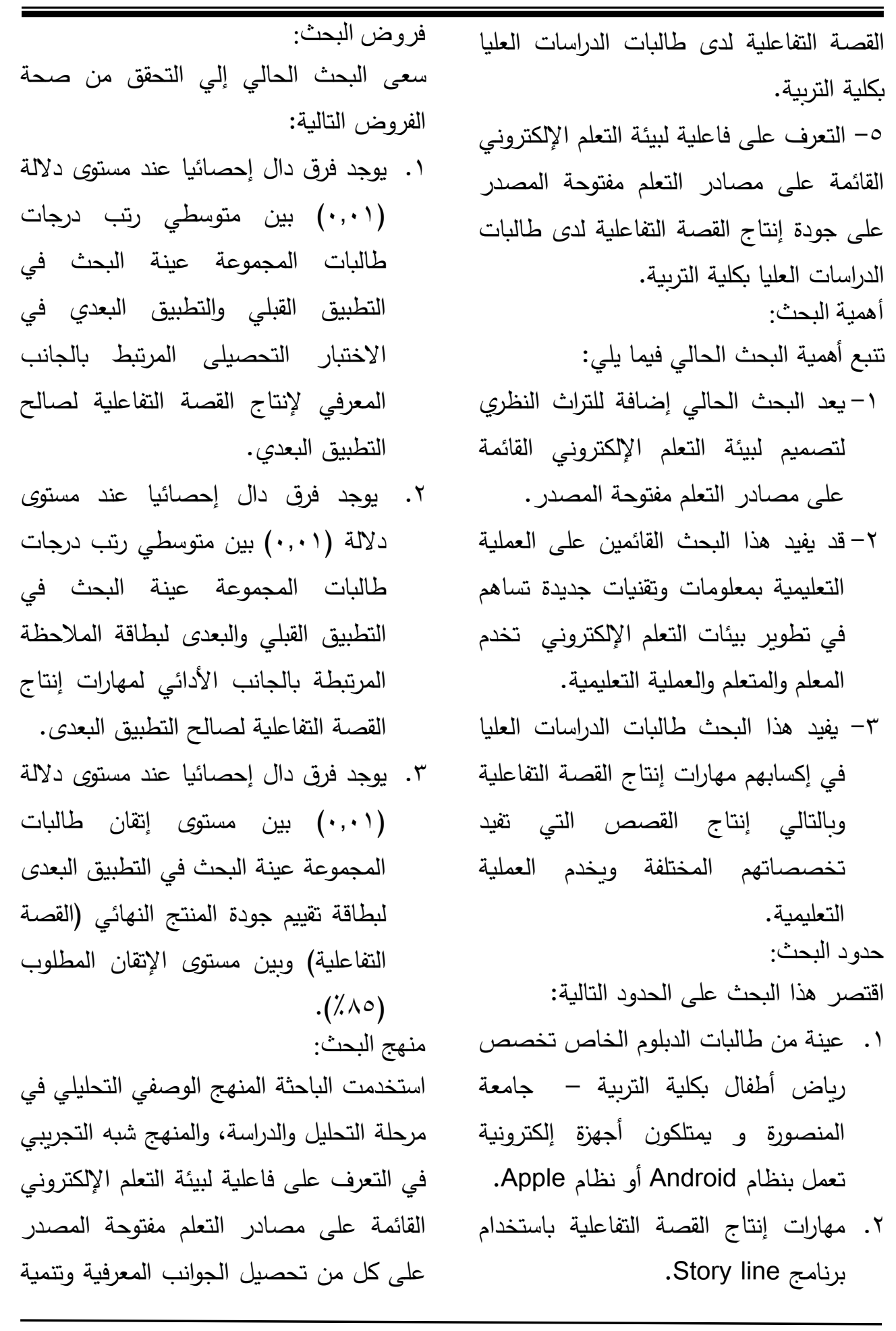


قامت الباحثة بتصميم أدوات البحث التالية:

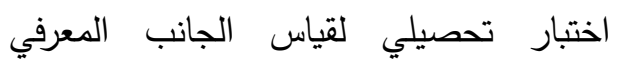
المرتبط بإنتاج القصة التقاعلية. ا. بطاقة ملاحظة لقياس الجانب الأدائي لمهارات إنتاج القصة التفاعلية.

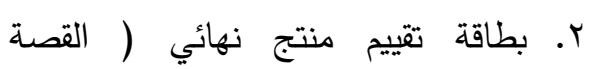
التفاعلية). مصطلحات البحث: - اته

ا ـ بيئات التعلم الإلكترونية: Electronic

\section{Educational Environment}

تعرف إجرائيا بأنها: بيئة تعليمية تحتوي علي

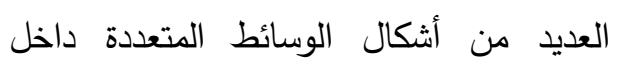
محتواها، وتتيح لطالبات الدراسات العليا من

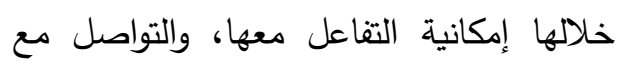
بعضهم البعض بشكل تزامني أو غير تزامني، وذلك من خلال توظيف مصادر التعلم مفتوحة المصدر التي تساعد الطالبات علي التعلم داخلها.

r. . مصــادر الـتـعلم الإكترونيــة مفتوحسـة

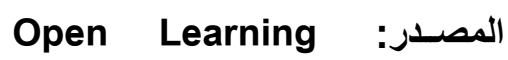

\section{Resources}

تعرف إجرائيا بأنها: المصدر البرمجي الذي

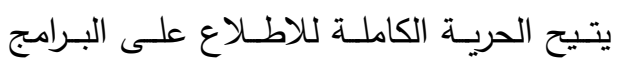

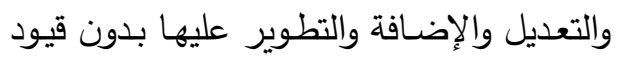

الملكية الفكرية. r. القصة التفاعلية: Interactive Story تعرف إجرائيا بأنها : مجموعة مواقف مصممة على شاشات جهاز الكمبيوتر تسمح للطفل
الجوانب الأدائية لمهارات إنتاج القصة التفاعلية..

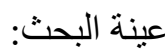
تكونت عينة البحث من عينة من طالبات

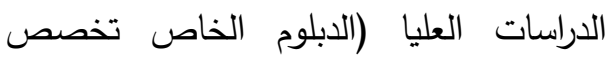
رياض أطفال بكلية التربية - جامعة المنصورة وعددها ( 9 (1) طالبة. التصميم التجريبي للبحث: استخدمت الباحثة في هذا البحث التصميم التجريبي القائم على المجموعة عينة البحث One Group Pre - Test Post - الواحدة Test Design لأدوات البحث وذلك لقياس فاعلية لبيئة التعلم الإلكتروني القائمة على مصادر التعلم مفتوحة

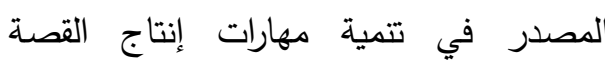
التفاعلية. متغير ات البحث: اشتمل البحث الحالي على المتغيرات التالية: 1- المتغير المستقل: بيئة التعلم الإكتروني

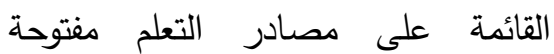

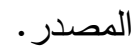

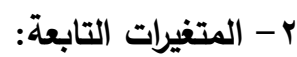
أ- التحصيل المعرفي المرتبط بإنتاج القصة التفاعلية. ب- الجانب الأدائي المرتبط بمهارات إنتاج القصة التفاعلية.

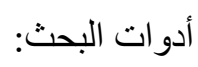




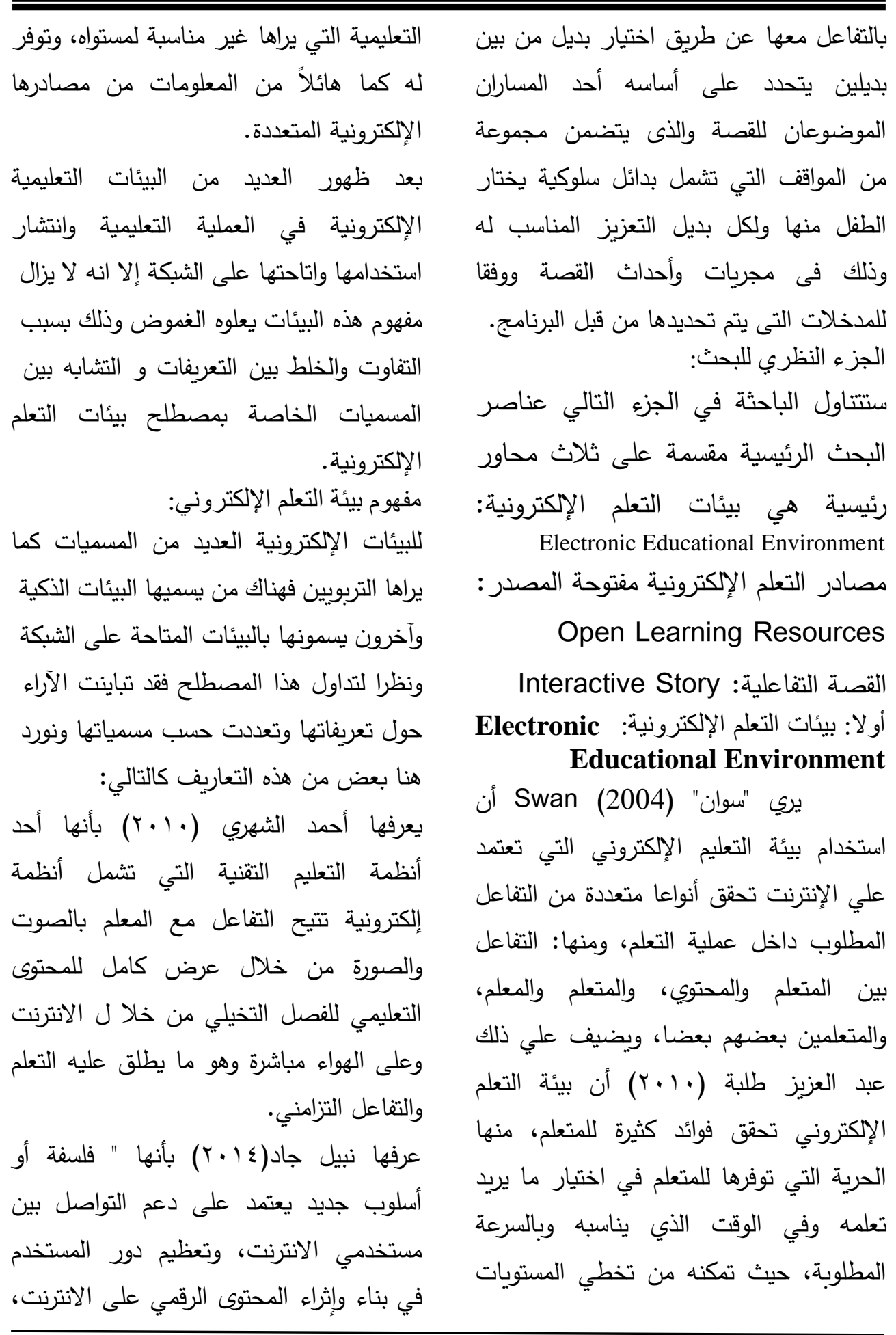




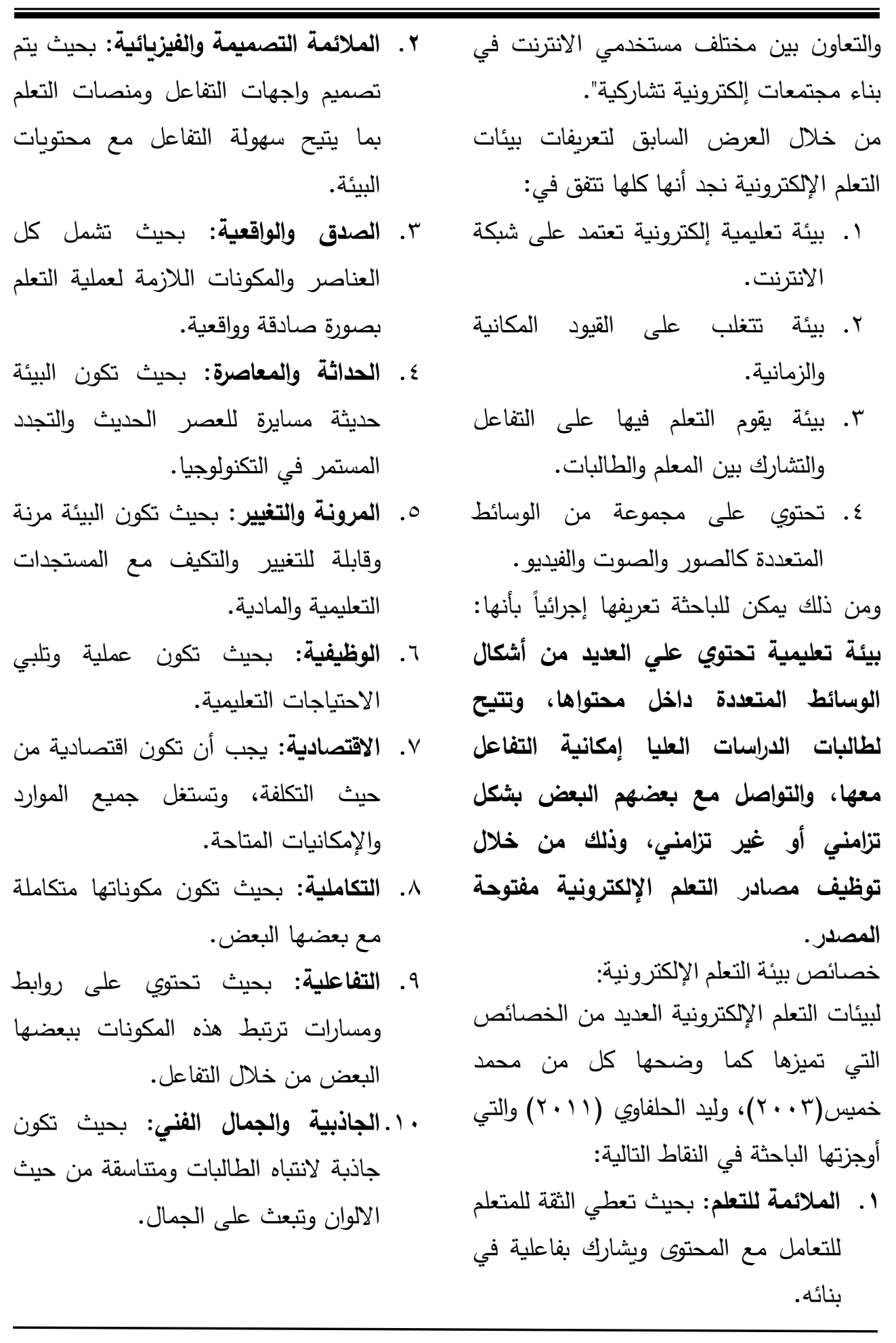


الإلكترونية يتم تصميم وإنتاج وعرض

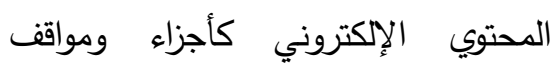
تعليمية، ويقوم بتتفيذ ذلك المؤلفون للمادة التعليمية، بينما تتحكم الإدارة التعليمية الإلكترونية في دورة حياة محتوي المقرر

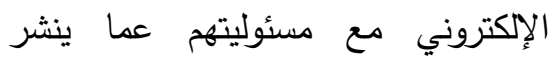
بالمحتوي الإلكتروني.

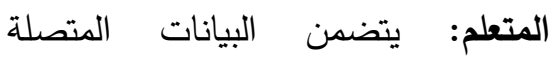
بالطالب، وأحيانا نحتاج إلى جمع بعض لبض باتش البيانات الخاصة بالطلبة من بيئات التعلم الإلكتروني المتعددة لتحديد خصائصه

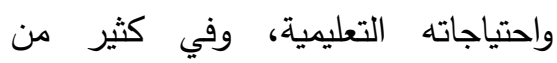
الحالات من الممكن أن ينتقل ملف وفئه الطالب من بيئة تعلم إلكتروني إلي أخري

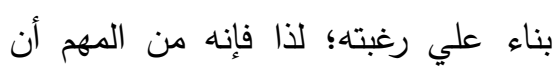
يكون ملف الطالب محدد المستوي بدقة وخالياً من التفسيرات الخاصة، والجزء الخاص بالطالب يتضمن بيانات الطالب الثخصية، ملفاً لشهادات الطالب ودرجاته باتهن بالمواد المختلفة، بيانات من حسابات الطالب ومصاريفه وفواتيره، بيانات تسجلها الإدارة التعليمية. نظام إنتاج مادة المحتوي الإكتروني:

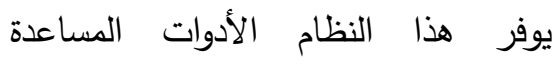
للمؤلفين لتصميم وإنتاج مادة المحتوي الادوات الإلكتروني، والتي تساعد المحكمين على لمدين تقييم المحتوي الإلكتروني، ويستخدمه
11 ا القابليـة للاسـتخدام: بحيث تكون مريحة

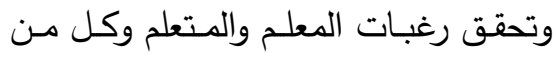

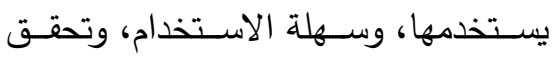
الأهداف بكفاءة وفاعلية.

وهو ما أكدته العديد من الدراسات والبحوث على أن لبيئة التعلم الإلكتروني مزايا عديدة مما يجعلها تعزز العملية التعليمية ومنها دراسة الئه

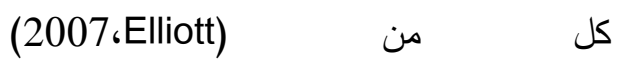
ودراسة(r) ول(2008،Gonzalez\& Louis) و نبيل

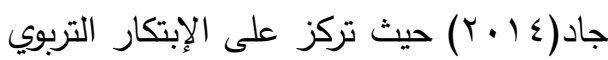
وليس التقنية في حد ذاتها، ومشاركة الأفكار والأراء والصور من خلال مواقع التواصل الإجتماعي، إبداء ومشاركة الآراء مع الآخرين

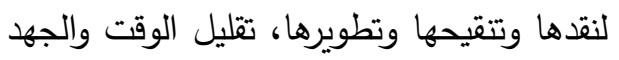
المبذولين في البحث عن المعلومات والتعامل مع الآخرين، تساهم في المعرفة المشتركة، تميزها بوجود محركات البحث التفاعلية التي يتفاعل معها المتعلم وتستجيب لاحتياجاته في الوصول للمعلومات المطلوبة، حفظ المواقع المفضلة لكل متعلم، عرض مقاطع فيديو للترفيه أو التعلم من خلالها، تعزيز وتوسيع خبرات المتعلمين في مجالات متنوعة. مكونات بيئة التعلم الإلكترونية: توجد العديد من المكونات الخاصة ببيئة التعلم الإككترونية، والتي تتاولها كل من (محمد

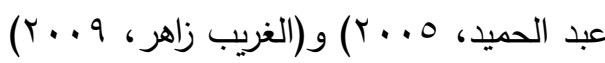
كما يلي: • المحتوي الإكتروني: في بيئة التعلم 
في المؤسسات التعليمية وتدريب المتعلمين عليها عنصرا محفزاً لكل من المعلم والمتعلم لاستخدام شبكة الإنترنت في العملية التعليمية،

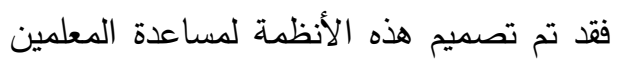
على استخدام شبكة الإنترنت في التدريس لتصني والتواصل مع المتعلمين بطريقة سهلة، والحصول على مواد علمية مختلفة ومتعددة

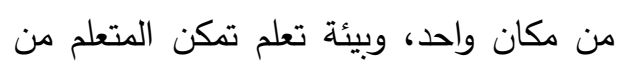
التفاعل بصورة إيجابية مع المادة العلمية.

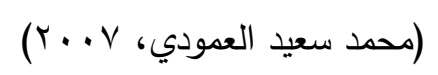

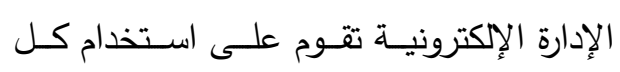

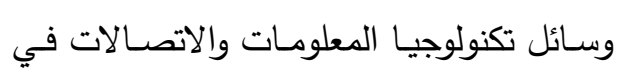
عمليات الإدارة، ولتسهيل تتفيذ عملية الإدارة تم

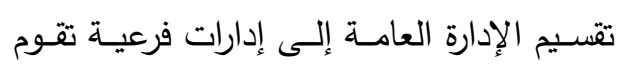

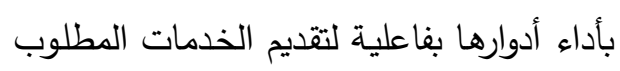
تحقيقها في أسـرع وقت بكفـاءة عاليـة وهـي كالتالي: ا ـ إدارة تسجيل ومتابعة البيانات إلكترونيا: تأتي عملية تسجيل بيانات الطالبات في المقام الأول لأي بيئة تعليمية، حيث أصبحت بئيلت عملية التسجيل من العمليات التي لها علاقة مباشرة في تحقيق الجودة وتحسين الأداء داخل البيئة التعليمية الإلكترونية.

\section{r. إدارة المحتوى الإكتروني:}

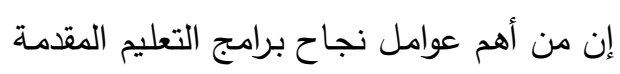
عبر الثـبكات في تحقيـق أهـافها هـي إدارة

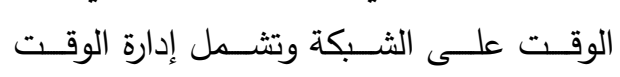

أيضا بعض من المسئولين عن إدارة مادة

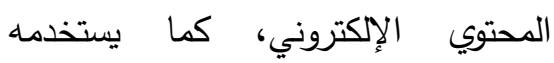

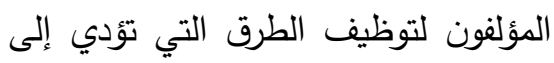
تكامل المقررات الجديدة مع المقررات التي لتولي التئي سبق عرضها، وتتضمن أدوات التثييم إمكانية أن يسجل المحكم درجات تقييمها ولهن

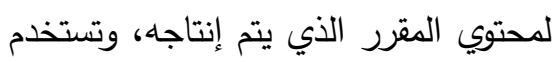

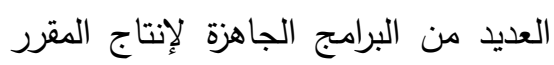
وإدارته.

نظام الحصول على البيانات: تعتبر من أهم

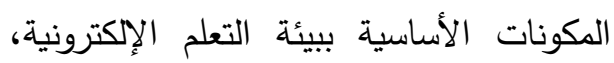

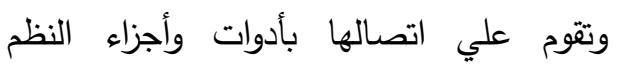
الأخرى، حيث تمثل جزءاً افتراضيا من أجزاء بيئات التعلم الإلكتروني، وتحتوي بيئات التعلم الإلكتروني على كثير من البيانات التي يجب توظيفها في عملية التعلم وحمايتها من سوء الاستخدام. نظم إدارة المحتوي الإكتروني: يتم من خلاله تمكين الطالبات من التحكم في عمليات تعلمهح من المحتوي الإكتروني المعروض، كما تمكن المعلم من الحصول علي معلومات عن مستوي أداء الطالبات والاستفادة من أدوات التقييم المتاحة. نظم إدارة بيئة التعلم الإلكترونية: تعد أنظمة إدارة التعلم الإلكترونية

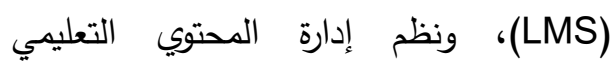
(LCMS) (LCMS)، الخاصة بمجال التعلم الإكتروني التحوي 


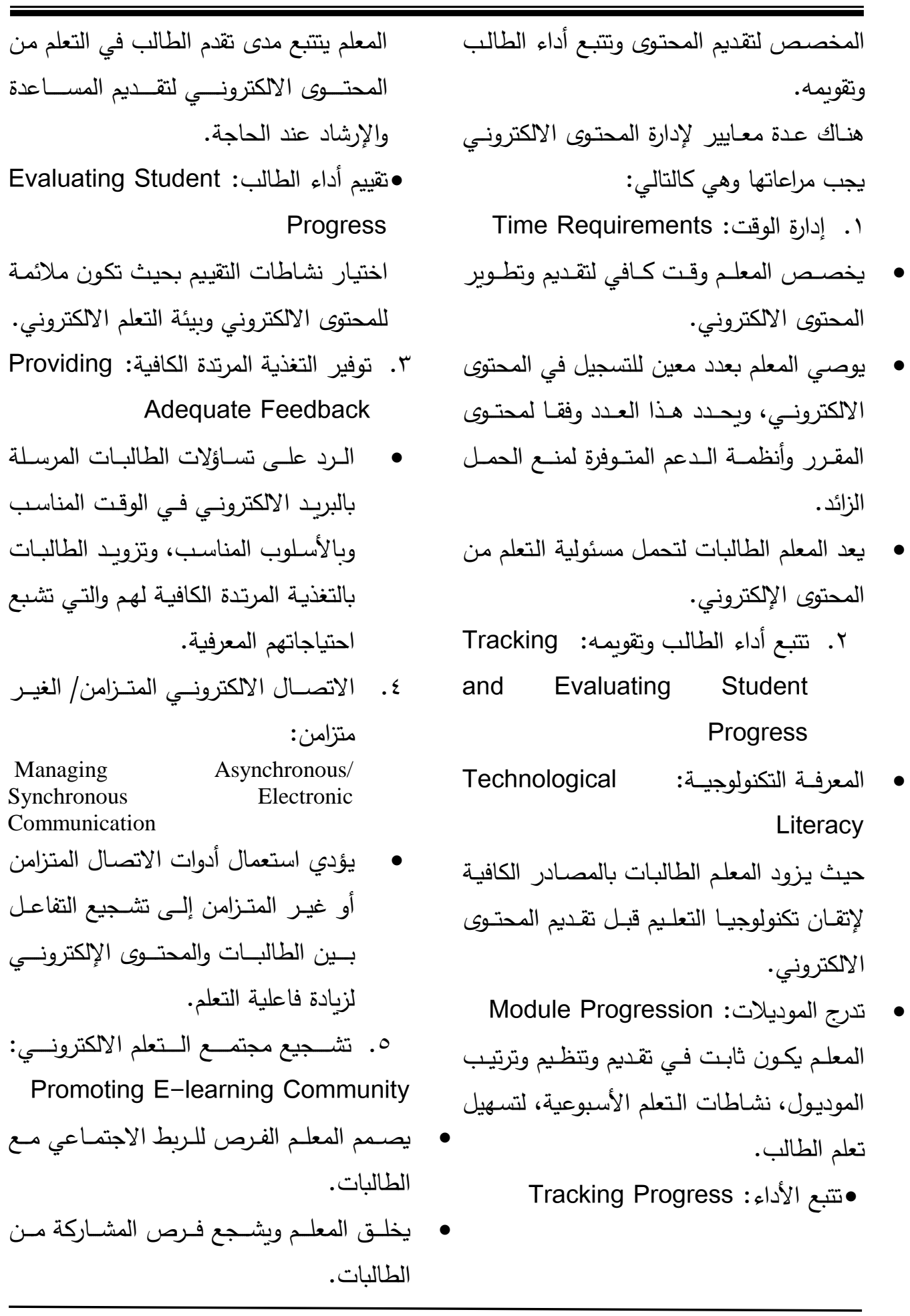




$$
\text { إلالا فـي وقــت متــأخر أو عنــــ الانتهـاء مـن }
$$

(ب) نمـط الاتصــال المباشـر ( المتـزامن )

\section{: Synchronous Communication}

هذا النمط في بيئة التعلم الإلكتروني لإتاحـة

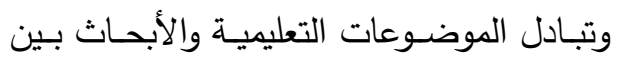

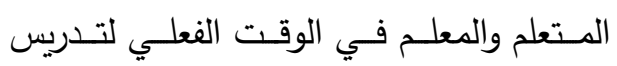
المحتوى نفسه، ومن أدوات الاتصال المتزامنة: المحادثة الفورية Real Time Chat ، أو الو

Electronic اللوحة البيضـاء الإلكترونية Instant White Board Massages حيث يستطيع الطالب الحصول ولتربن

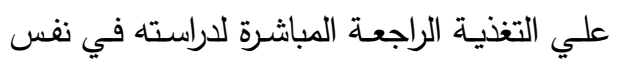

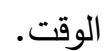
ع. إدارة الاختبارات والتقويم للطلبة:

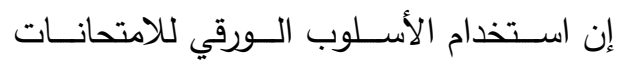
الفصلية قد لا يحقق العدالة، لذا فإن استخدام الاختبارات الإكترونية يحقق سرعة في الانجاز وتقييم أفضل للامتحانات كما أنه يحقق العدالة للطلبة، وأصبحت كثير من الجامعات العربية تطبـق نظــام الامتحانـات الفصــلية والنهائيــة إلكترونيا حيث يتيح لكل طالب أن يأخذ رقم

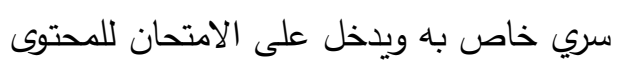

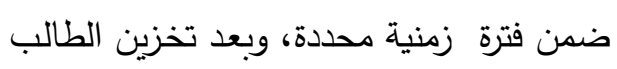

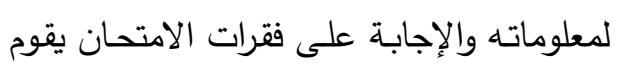
النظام بإعلان نتيجة الطالب وإرسالها الكترونيا إلى نظام القبول والتسجيل. وهذه الطريقة تقلل
يبذل المعلم جهد متزايد لتحسين التواصل بين المتعلمين وبعضـهم البعض، وبـين المتعلمين والمعلم. r. إدارة الاتصال بين الطلبة والأساتذة:

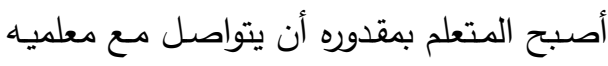

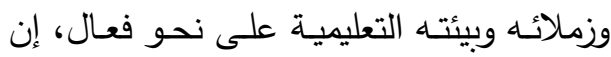
تكنولوجيا المعلومات والاتصالات سـاهمت في وبله تسـهيل التواصـل والتحــاور وتتويـع الأنشـطة

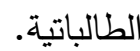
إن أكثر أنماط الاتصـال شيوعا في بيئة التعلم الالكترونـي وهـي تثـري هــه البيئة، وتتمسي

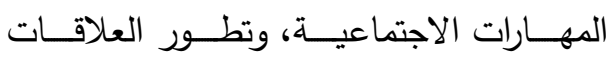
الشخصية بين المتثـاركين، وتدعم استقلالية

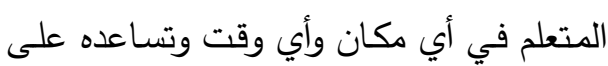

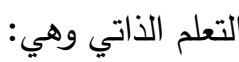

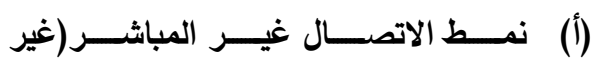

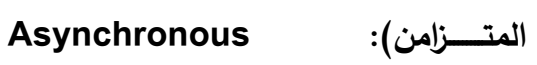

\section{Communication}

يحصـل المـتعلم مـن خـلال هـذا النـوع مـن الاتصــال علــى دروس مكثفــة وفـق برنــامج دراسـي مخطط ينتقي فيـه الأوقـات والأمساكن

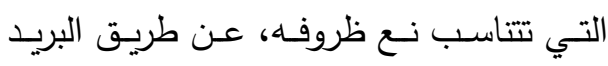

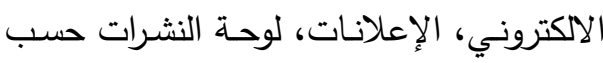

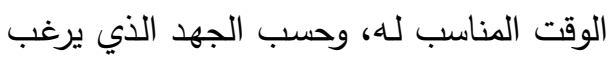
في إعطائهه، ويستطيع الطالب إعـادة دراســة

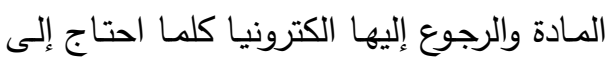

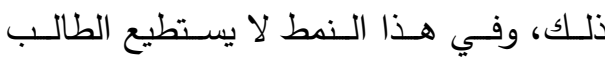

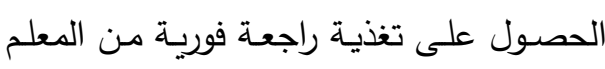


من استخدام الكثوف الورقية، وتقلل من الوقت تقديم عرض لأهم متطلبات التحول نحو بيئة

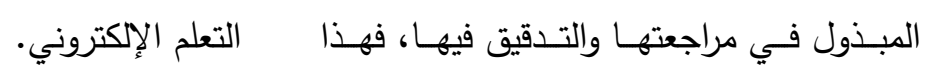
متطلبات التحول نحو بيئة التعلم الإلكتروني: يتطلب الانتقال من بيئة التعلم التحرن الحالية إلى بيئة التعلم الإلكتروني إجراء العديد

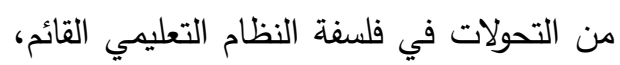
وفي بيئته، ولدي المعلمين والمتعلمين، وقد في

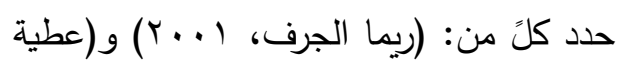

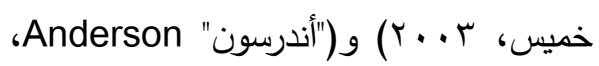

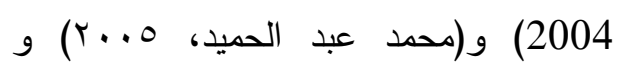
(ميسون عادل، r Y (Y) أهم هذه المتطلبات فيما يلي: 1-التحول من نظريات التعلم السلوكية إلى

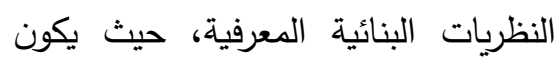
المتعلم إيجابياً نشطاً، يبني تعلمه بنفسه ولا يستقبله من المعلم. r- تحول فلسفة التربية من التعلم المتمركز

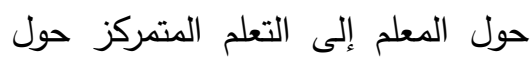

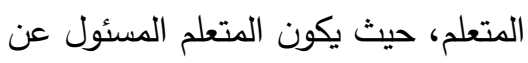
تعلمه. r- التحول من تحكم المعلم في التعلم إلى تعلى تحكم المتعلم فيه، حيث يتحكم في تحديد تعلمه الخاص وإدارة أنشطته.

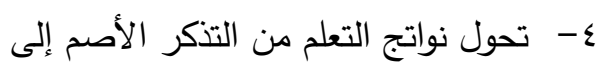
الفهم والإبداع وحل المشكلات، ولقد أثبتت الدراسات أن المتعلمين يفضلون هذه الوسائل التقليدية إذا كان هدفهم هو التعمين

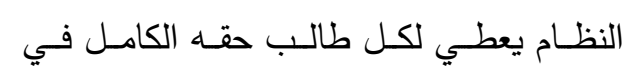
العلامـات دون تدخل العنصـر البشـري وتأثير العلاقات الثخصية في تتييم الطالبات. معوقات تطبيق بيئات ألتعلم الإلكتروني: لئي

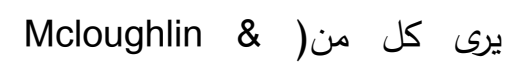

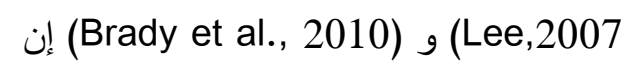
هناك بعض العقبات التي تواجه تطبيق بيئات التعلم الإككترونية في العملية التعليمية تذكر لفئ لفئي فيما يلي: • عدم الحفاظ على خصوصية المتعمين باستخدام بعض الثبكات الاجتماعية الموظفة في العملية التعليمية. وجود آليات مستمرة لمتعابعة موثوقية ومصداقية المحتوى الذي يمكن أن يصل لئل إليه المتعلمون. مراقبة إبداعات المتعلمين من خلال التأكد

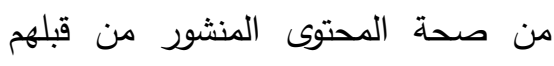

$$
\text { وهو ما يسسب في قيود الابداع لديهم. }
$$

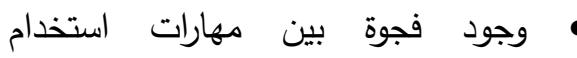

المعلمين والمتعلمين لتطبيقات بيئة التعلم الإلكتروني وهو ما يسبب عدم الانسجام

$$
\text { بينهم لافتقار المعلمين لهذه المهارات. }
$$

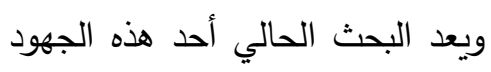

التي تسعى لإيجاد بيئة تعليمية إلكترونية

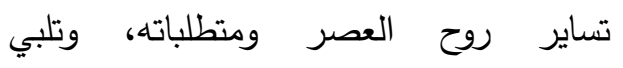
احتياجات المعلمين والطالبات، وسوف نحاول 


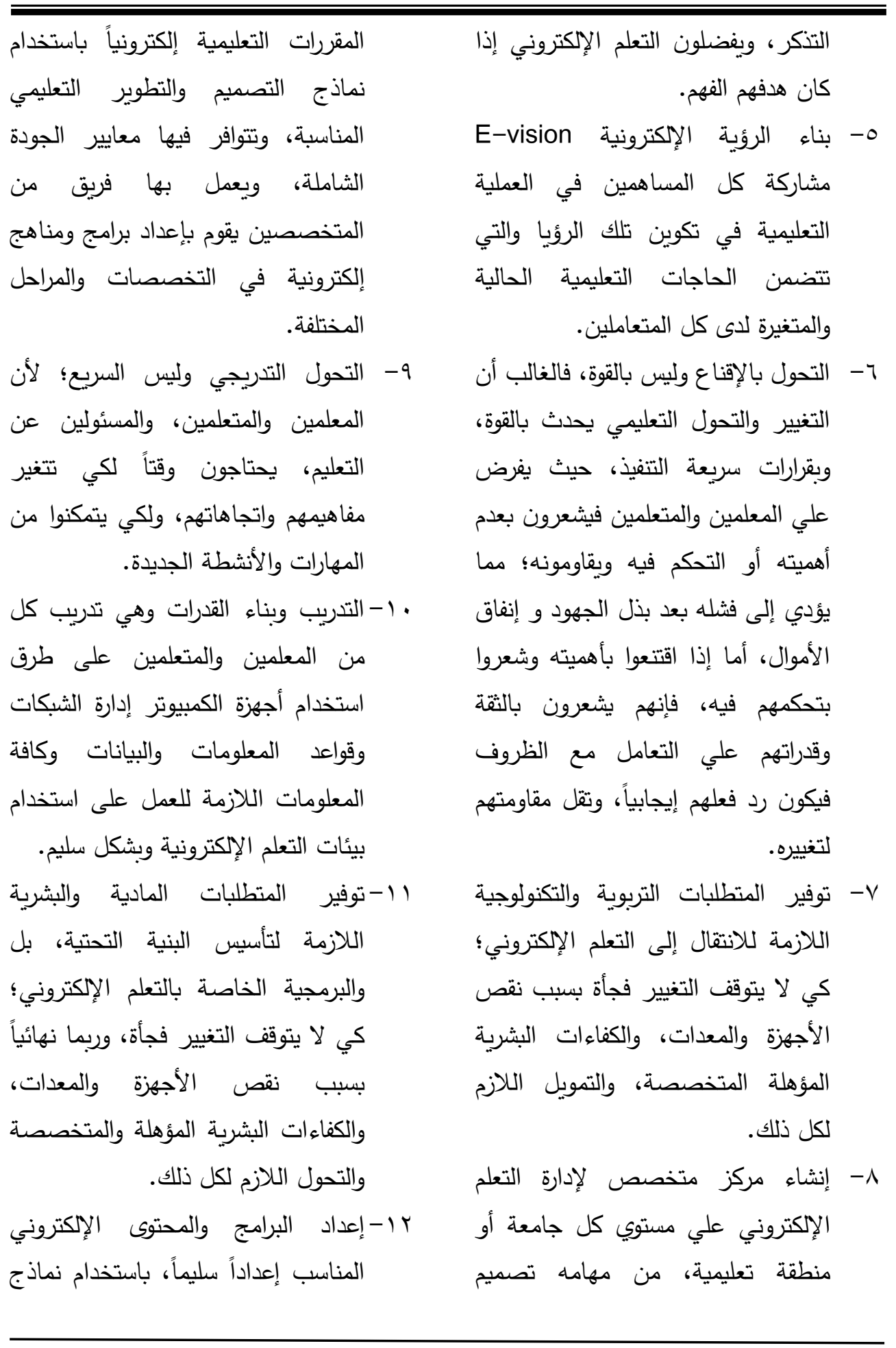


التصميم والتطوير التعليمي المناسبة؛ المجال التكنولوجى بصفة خاصة يساعد

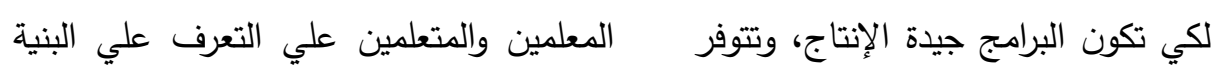

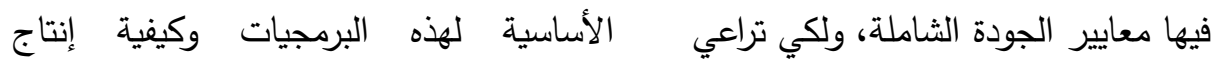

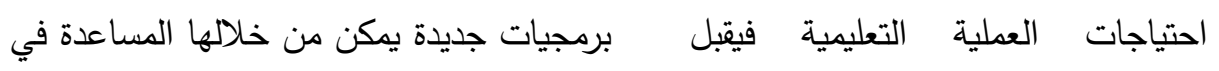
المعلمون والمتعلمون علي استخدامها. إدارة عمليتي التعليم والتعلم بصورة جيدة.

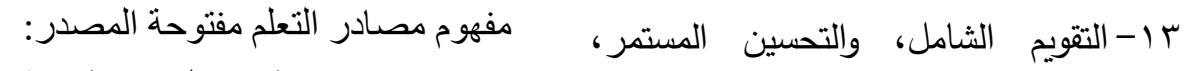

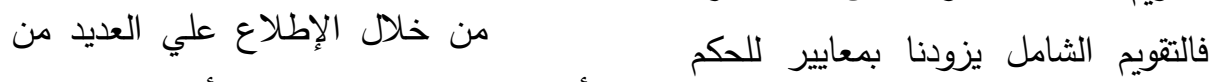

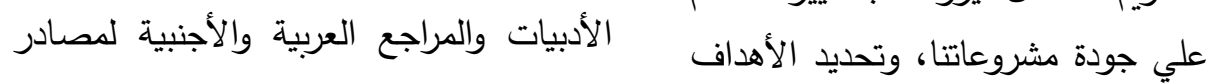

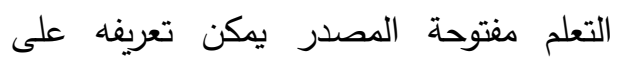
النحو التالي: - النعل

Rolfe, V.2012) تعرفها رولف:

بأنها: "ملفات وبرامج ومواد وأدوات وخدمات

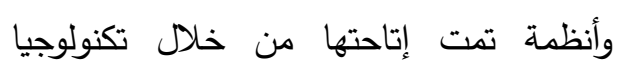
المعلومات والاتصالات للتعديل والاستخدام لأغراض غير تجارية مجانية بدون أي شروط أو تراخيص استخدام، متاحة علي الإنترنت للاستخدام في أي وقت ومن أي مكان سواء

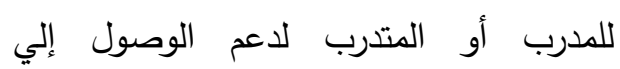
المعرفة." - - المدرب

ويعرفها حسن الباتع، السيد عبد

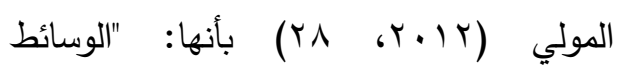
التعليمية الإلكترونية المتنوعة، والموجودة علي ليكاني شكل رقمي، ويتقاعل معها المتعلم في إطار

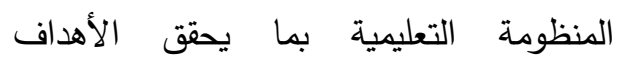

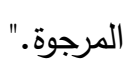

ويعرفها عطية خميس(10) بأنها:" مصادر تعلم مجانية أو بتكاليف قليلة،

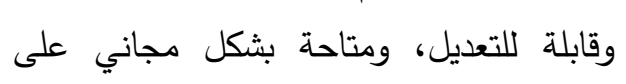
التي حققناها بكفاءة وفاعلية، والتحسين المستمر في ضوء نتائج التقويم المستمر ولئر

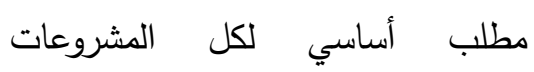
التعليمية، خاصة الإكترونية منها؛ لكي تواكب مستحدثات العصر ومتطلباته. يتضح من العرض السابق أن هناك مظاهر عديدة للتحول نحو تطبيق بيئة التعلم الإلكتروني في جميع مؤسساتتا التعليمية؛ وذلك نطئ

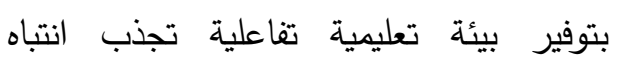

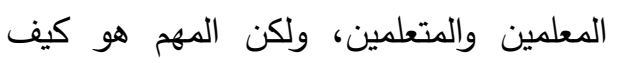
نتحكم في هذه البيئة الإكترونية أو كيف يمكن ولكن إدارة المقررات التعليمية، والأنثطة داخل هذه

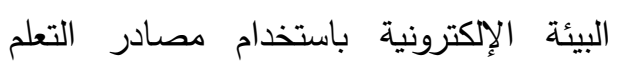
مفتوحة المصدر وهو ما سوف نتتاوله في المحور التالي.

Open نانيا: مصادر التعلم مفتوحة المصدر Learning Resources إن استخدام مصادر التعلم مفتوحة المصدر في مجال التعليم بصفة عامة، وفي 
تتيح لمستخدميها حرية الحصول على مصدر هذه البرامج، مع إمكانية تعديلها

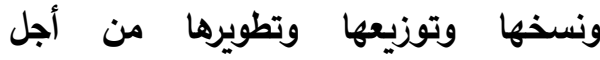
استخدامها وتوظيفها لتنمية مهارات إنتاج القصة التفاعلية فى ضوء بئئة التعلم الإلكتروني التي ستقوم عليها هذه المصادر." خصائص مصادر التعلم مفتوحة المصدر: تعـددت الخصـائص التـي تتيحهـا مصسـادر التعلم مفتوحـة المصـدر، ويـذكر كلاً من "الاخان وكافيتا" Lakhan, S.\& "Kavita, J. (2008) Jennings, D. (2010)

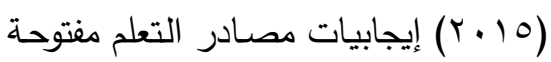
المصدر وخصائصها في النقاط التالية:

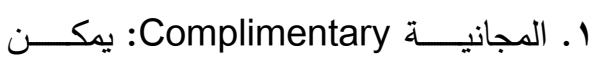
الحصـول علي البرامج دفتوحـة المصدرر

$$
\text { والملفات والأنظمة مجانا. }
$$

r. غير مقيدة Unrestricted: وذلك يعني أن ليس لها فترة محددة للاستخدام، فهي مفتوحسة دائمـاً ومتـوفرة لجميـع المتـدربين للاستخدام المفتوح. ץ. الانتشــار Expanded: أي أنهـا متـوفرة

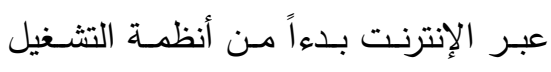
مثل الينوكس Unix المفتوحة وحتي برامج سطح المكتب البسيطة وملفات الوسـائط المتعددة وأنظمة إدارة التعلم.

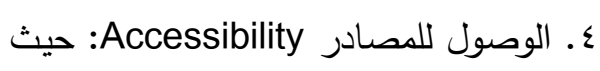
أنهـا ذات صـفـة تفاعليـة متزامنــة وغيـر
الخط، ويمكن لأي فرد(معلم، متعلم، تعلم ذاتي) إعادة استخدامها في التعليم والتعلم والبحث، إما كما هي، او عن طريق إعادة صياغة أهدافها، ودمجها مع مصادر أخرى." وبذلك يتضح أن مصادر التعلم

$$
\text { مفتوحة المصدر هي: }
$$

ا . برامج مجانية مفتوحة للتعديل فيها متاحة

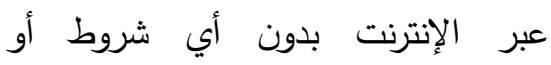
تراخيص استخدام.

r. أي كيان رقمي أو غير رقمي يمكن إعادة

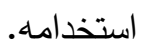
r. ملفات عديدة ومتتوعة مجانية غير تجارية

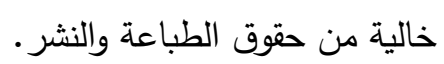

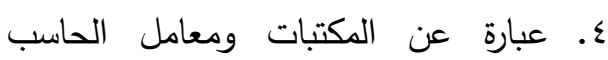
واللغات والقاعات والجامعات الافتراضية

$$
\text { والوسائط الإلكترونية. }
$$

0. وحدات صغيرة ومتعددة يتم تخزينها في ولئه مستودع ليتم التعديل بها لتلائم البيئات

$$
\text { التعليمية. }
$$

T. . متاحة للمعلم والمتدرب في أي وقت ومن أي مكان. V. أي مصدر رقمي مفتوح المصدر مجاني، مكان.

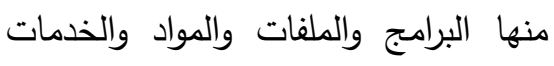
والأنظمة. وبهذا يمكن الخروج بتعريف إجرائي لمصطلح مصادر التعلم مفتوحة المصدر علي أنها: "عبارة عن حزمة من البرامج والملفات 
علـي نوعيـة وكفـاءة مخرجـات التـدريب

لديهم.

تصنيف مصادر التعلم مفتوحة المصدر وطرق توظيفها في إنتاج القصة التفاعلية:

توجد أنواع متعددة ومختلفة من مصـادر الـتعلم التي تهيـئ للمتـدرب فـرص التـدريب الذاتي، وتساعد في تعزيز التعليم لدياه، حيث صـنفها محمـد عطيـه خميس (10 ب r) إلـي:

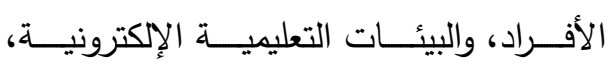

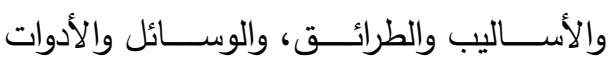
والتطبيقات، والتي يوضحها الثكل التالي:

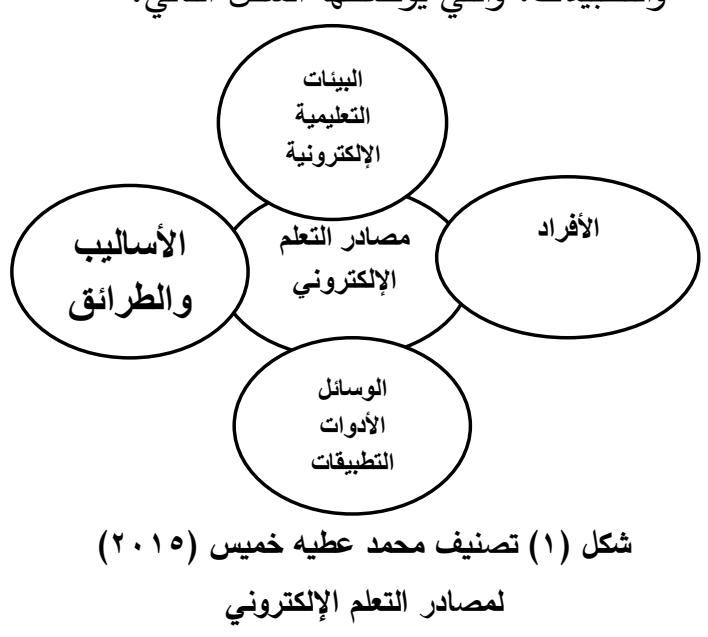

وصنفها أيضاً كلاً من ريهام الغول، أمين الاكروني صـلاح الدين (10 • ب) إلي مصـادر بالتصميم

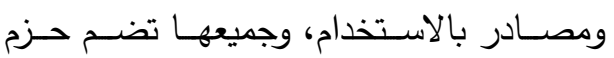

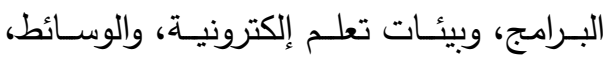

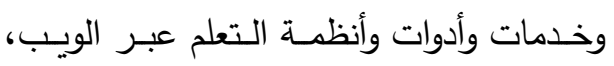

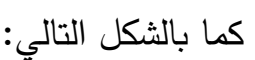

متزامنــة يسهـل اسـتخدامها مـن أي مكـان

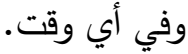

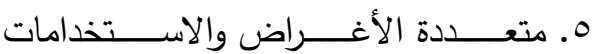
Versatile والاسـتخدامات بـأكثر مـن طريقــة يراهـا

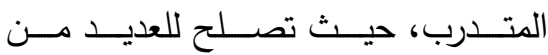

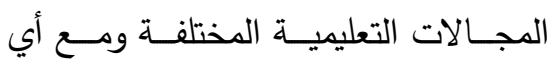
محتوي تعليمي لأنها تتناسب وتتلائم مـع البيئــات التعليميـة الإلكترونيــة المختلفــة والتطورات الدائمة والمتجددة في تكنولوجيا

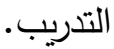
7. مــوفرة Providing: حيـث تـوفر للمعلــ

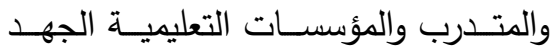
والوقت وتكاليف الإنتاج والثراء للملفات والبـرامج وتصـميم مواقـع لرفـع الأعمــال والمهام التعليمية عليها.

V. المشــاركة Shareable: لكثــرة أنواعهــا يمكـن أن تسـتخدم فـي أكثر مـن مقـرر تعليمي وبأكثر مـن طريقة، ويمكن نقلهـا من مكان لآخر بدون شروط أو قيود إما

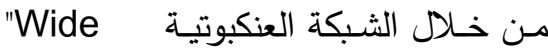
"WAN" Area Network" LAN "Local Area الداخليـة "Network" خلال وسائل التخزين المتاحة المعروفة. 1. الفرديـة Individualization: حيث أنها تتناسب مـع احتياجـات المتدربين وتؤثر 


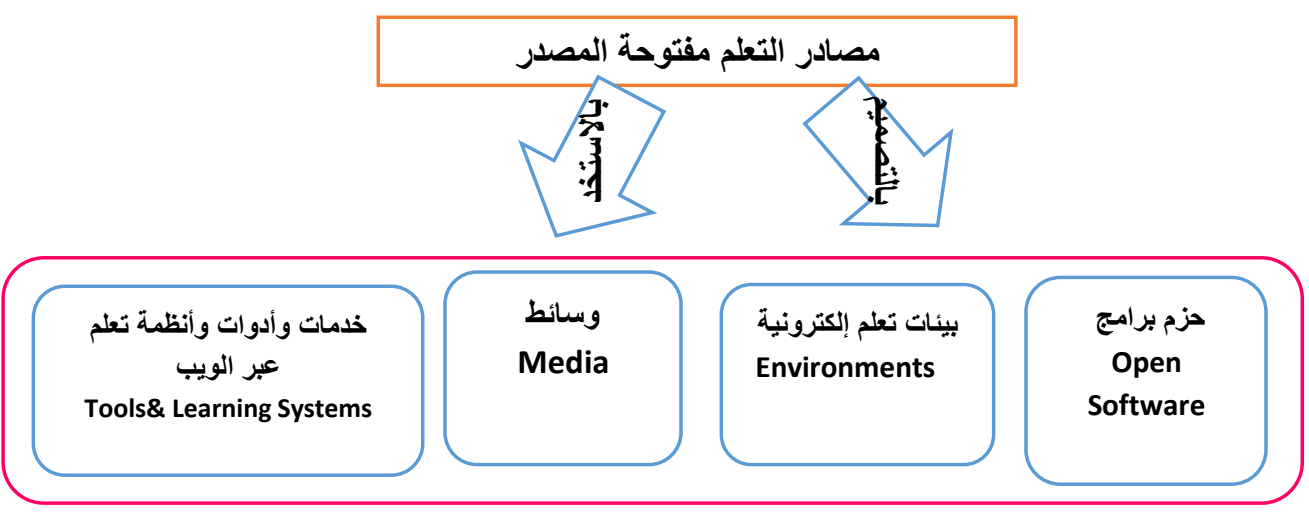

شكل (Y) تصنيف ريهام النول، أمين صلاح الدين (10 ب r) لمصادر التعلم مفتوحة المصدر التعليم والتدريب، لذا سيتم توظيفها في إنتاج القصسة التفاعلية، وهو ما يسعي البحث الحالي إلي تحقيقه من خلال تدريب طالبات الدراسات العليا من خـلال بيئة التعلم الإكترونـي القائمـة علي توظيف مصسادر التعلم مفتوحسة المصدر لإنتاج القصـة التفاعلية، وسيتم هذا الإنتاج من

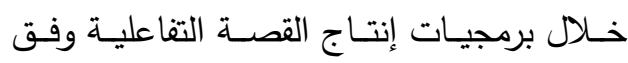
برنامج Story Line. سلبيات مصادر التعلم مفتوحة المصدر وعوائق

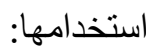

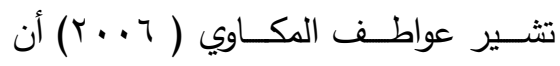
برمجيات المصدر المفتوح لا تكون علي درجة عالية من الكفاءة، لأنها نتاج جهود محترفين هواه، ولأن الهدف الأساسي من طرح البرنـامج هو تحقيق الثهرة للمطور أو المطورين. أسس اختيار مصادر التعلم مفتوحة المصدر:

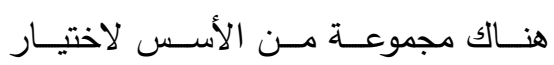

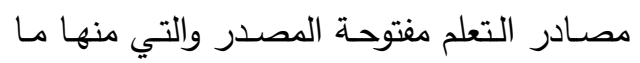
هو مرتبط بالموقف التعليمي ذاته، كما وضحها كــلاً مــن (ريهــام الغـــول، أمــين صــــلاح

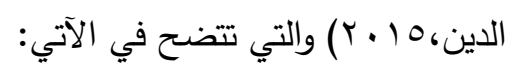

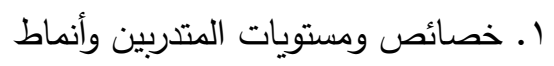

$$
\text { تعلمهم. }
$$
r ـ طبيعة الأهداف والمهمات ومجالها. r. طبيعة الخبرة التعليمية ـ ـ طبيعة المحتوي الإلكتروني. هـ الإستراتيجيات والأنشطة الإككترونية. 7 . الموارد والتسهيلات المتاحة. من خـلال ماسبق تتضـح أهميـة استخدام

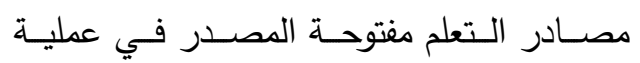




\begin{tabular}{|c|c|}
\hline الطالبات والتواصل معهن والتقييم المستمر & ويرى محمد اللهيبي (T . ץ) أن مجانية \\
\hline ل ل ان. & النظم المفتوحة المصدر ليست مطلقة، وذلك بما \\
\hline r. . ـ بالإضافة إلي استخدام العديد من الوساتط & تحتاجـهـ هـذه الـنظم مـن خبـرات تقنيـة لإعـادة \\
\hline المتعددة والكائنات الرقمية للقصص التفاعلية & تكييفها وصيانتها، وعليه فإن المؤسسات التي \\
\hline والتـى توجـد فـى بيئسة هـذه المصــادر مـن & لـــيس لــديها خبـراء فــــ البرمجـــة وتقتنيــات \\
\hline نصوص وصور ومؤثرات صوتية وموسيقية & المعلومــات عليهــا مقارنــة التكلفــة بـين الـنظم \\
\hline ورسوم ثابتـة ومتحركـة ودليل للمصطلحات & التجارية وتكلفة الاستثمار في جلب هذه الخبرات \\
\hline والتواصـل بين المعلم والطالبـات والطالبـات & قبل اتخاذ القرار في تبنى مثل هذه النظم. \\
\hline بعضهم البعض. & وتضـيف حنـان صـبري( ( 1 ـ ץ) أن مـن \\
\hline ع ـ اســتخدلم بعـض تطبيقــات بيئــات الـتـعلم & سلبيات مصـادر التعلم مفتوحة المصدر أنها لا \\
\hline الإلكترونـي مثل الفـيس بـوك لرفـع أنشــة & تـدعم اللغــة العربيـة فـي البحـث والاسـترجاع، \\
\hline 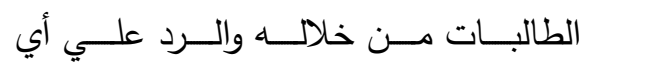 & 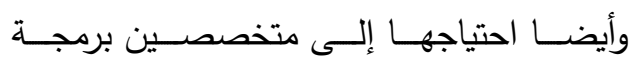 \\
\hline استفسـارات أو أسـئلة موجهـة مـن الطالبـات & لتثبيتها، والقرصـنة والسرقة وقلـة الإعـلان عنهـا \\
\hline للباحثة، وأيضـاً الويكي لرفع الباحثة البرامج & وتعارض البرمجيات مفتوحة المصدر . \\
\hline المرتبطة بإنتاج القصة التقاعلية من خلالها، & من خلال ما سبق تتضـح العلاقة الوطيدة \\
\hline كـي تكـون متاحسة لرجـوع الطالبـات وقـت & بين المتغيرين المستقل المتمثل في (بيئة التعلم \\
\hline الحاجـة إليهـا أثثـاء التطبيـق العملـي لتـلك & الإلكتروني القائهـة علي توظيف مصادر التعلم \\
\hline 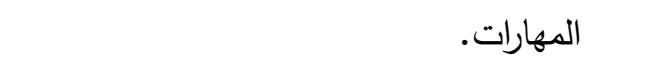 & مفتوحة المصدر) والمتغير التابع (مهارات إنتاج \\
\hline ثالثا: القصة التفاعلية. Interactive Story & القصة التفاعلية)من خلال ما يلي: \\
\hline إن القصة عبارة عن مجموعة من المواقف & ا ـ الاعتماد علي البرامج المجانية: مثل برنامج \\
\hline المرتبطـــة مــع بعضــهـا لتكــون نسـيج يشـــل & storyline2 وهو برنامج مخصص لتصديم \\
\hline مضمون له بداية ومحتوى ونهاية، لذا فإن الدور & القصص التفاعلية وهو يتميز بأنـه برنـامج \\
\hline التربوى الذى تحدثـه القصــة فى تتميـة جوانب & 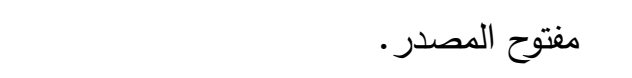 \\
\hline النمو المتكاملة لدى الطفل قد تزايد مع استخدام & ץ. إمكانيــة الاســتفادة مــن نظـــام التشـــغيل \\
\hline آليات وتكنولوجيا تقديم المعلومات والمعرفة. & Moodle وهو أيضـاً مفتوح المصدر والذي \\
\hline العناية بأدب الأطفال وقصصهم وثقافتهم & يـدعم اللغــة العربيـة في رفع المحتوي مـن \\
\hline يعد مؤثرا لتقدم الدول، وعاملا جوهريـا فى بناء & خلاله علي الشبكة، وإمكانية تسجيل أسماء \\
\hline
\end{tabular}


مستقبلها وهذا يرجع إلى أهمية القصـة بالنسبة والاسـتجابة لهم، ويعطيهم درجـة مناسـبة مـن

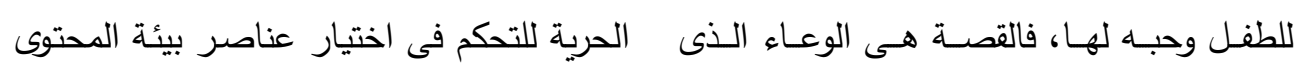

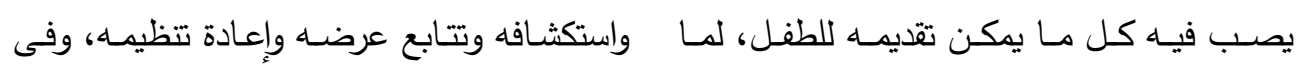
تحمله مـن معـان وصـور جديدة مـن الحياة لا سرعة الخطوات والمشاركة الإيجابية فى التعلم".

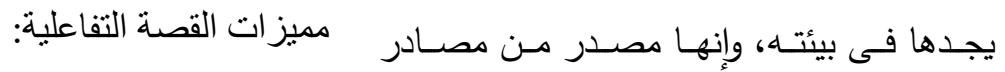
تــكر داليـا العـدوى( 10 • باعلة) مميـزات

استخدام القصص التفاعلية في التعليم بأنها: تحسن من استيعاب المتعلمين.

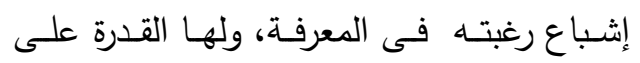
إمتاع الطفل وإثارة خياله، هذا إلى جانب مـاتها يتميز بـه النشـاط القصصسى من سحر وخيان تعطي فرصــة لخيـال المتعلم في تحليل العيل وتقسير أحداث القصة. تبعد الملل عن المتعلمين.

توظف جميع الحواس لدى المتعلمين. ومتعة وهو نشاط يمكن أن يكون هادفا فى حد

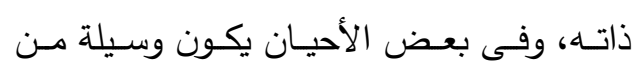
وسائل التثقيف مفهوم القصة التفاعلية: تجعل عملية انتقال المعلومـات تتم بشكل سهل وميسر . تجعل عملة تضيف المتعـة والتسلية إلى عملية التعليم والتعلم. تصن.

تكسـب المتعلمـين مهـارات النقد والحـوار والتحليل.

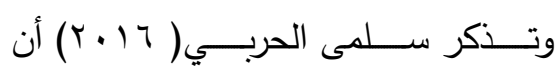
القصص التقاعلية تقدم العديد من المزايا للعملية التعليمية وذلك لأنها:

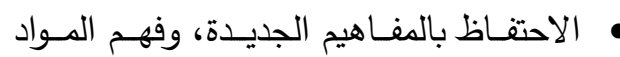

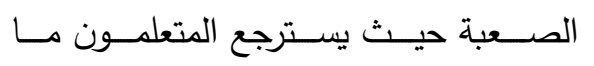
وتعرفها الباحثة إجرائيا بأنها "هى اتصـال

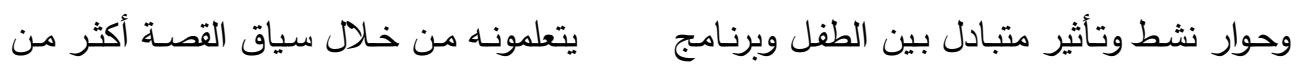

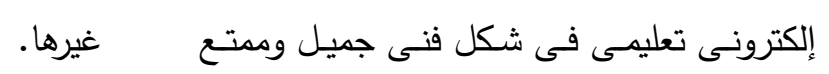

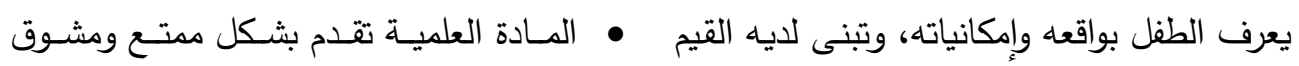
والاتجاهـات السـليمة والضـمير الحسى، ولديـهـ ومثير.

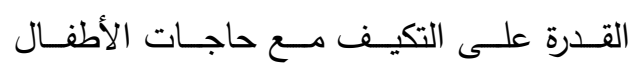




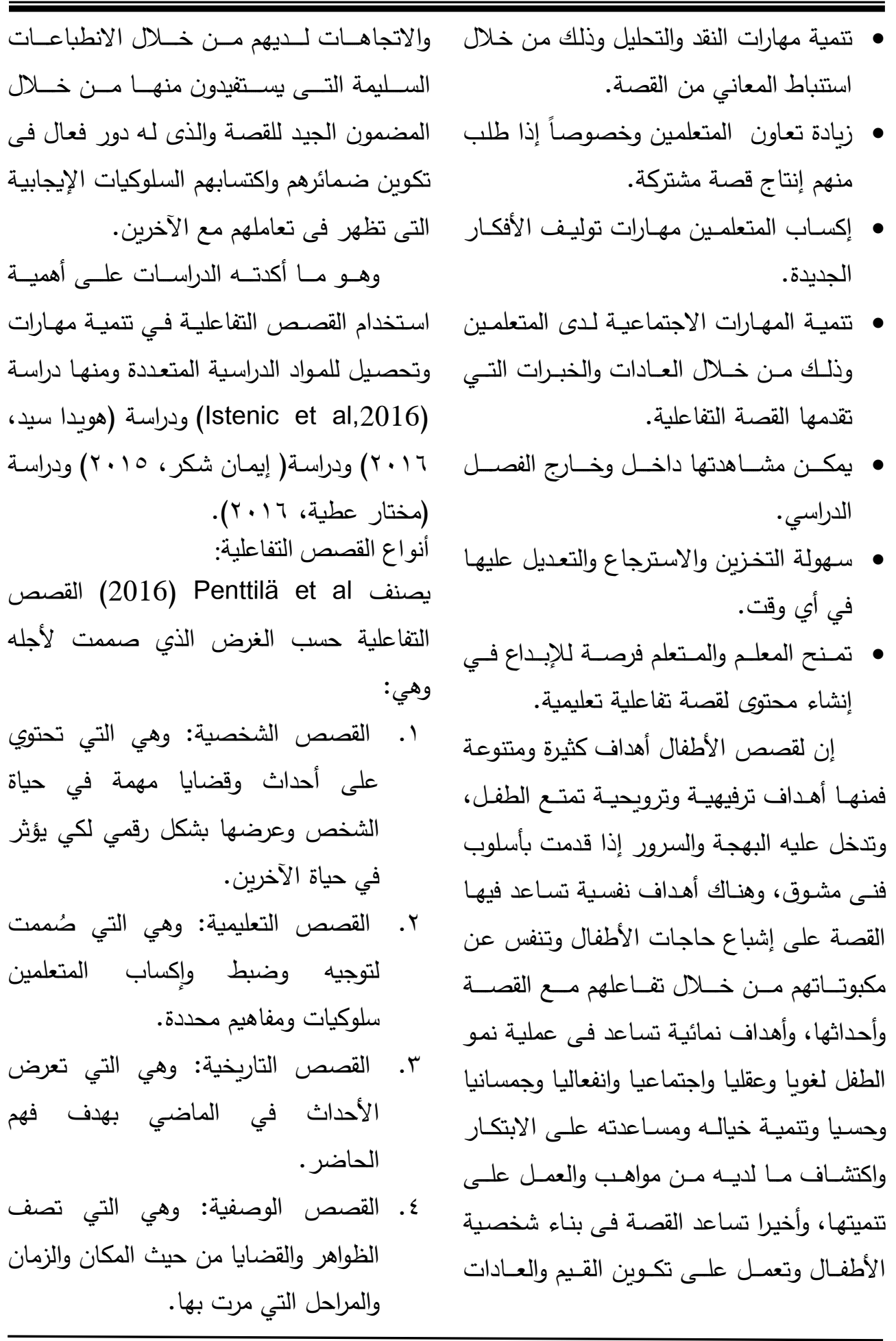




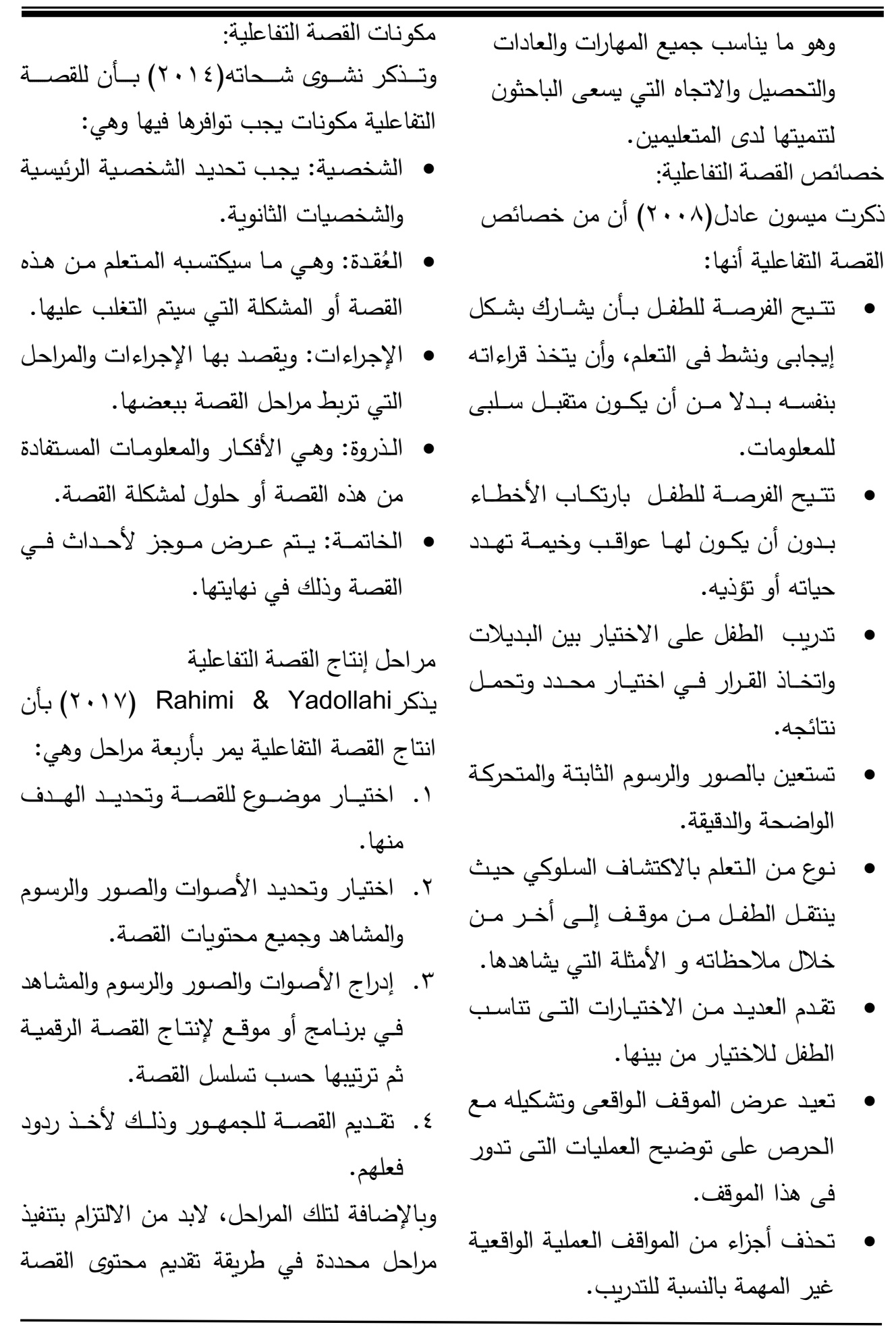


ثم إجراء كافة التعديلات المطلوبة للوصول بقائمة المهارات المطلوبة إلى صورتها النهائية.

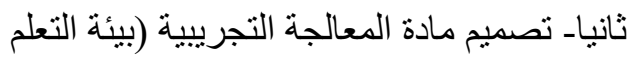
الإلكتروني القائمة على مصادر التعلمة التحلم مفتوحة المصدر): الإكتروني تم تصميم بيئة التعلم الإلكتروني القائمة على مصادر التعلم مفتوحة المصدر بعد الإطلاع لئه

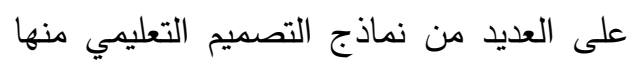

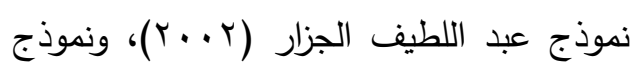

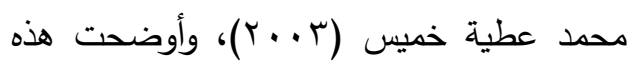

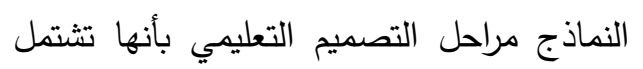

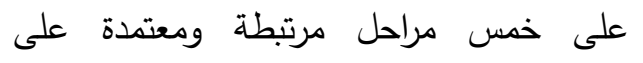

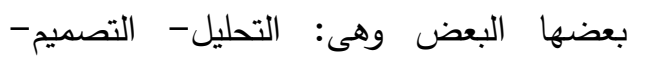
التطبيق والتقويم- النشر والاستخدام، وبعد الإطلاع على هذه النماذج تم اقتراح نموذج مناسب لتصميم بيئة التعلم الإلكتروني القائمة على مصادر التعلم مفتوحة المصدر كالتالي:
وذلك لثد انتباه المتلقين حيث تثير إيمان

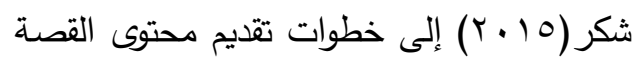

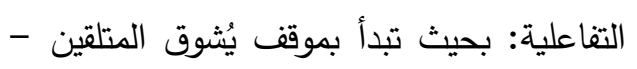
وهذا الموقف يعرض مشكلة ما- وبعد ذلك تمر بئري لعرضٍ مفصلٍ لهذه المشكلة، ليتم -في نهاية

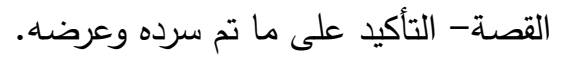

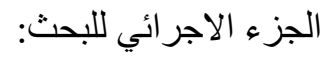
للإجابة عن أسئلة البحث، والتأكد من صحة الفروض اتبعت الباحثة الإجراءات التالية: أولا- تحديد قائمة بمهارات إنتاج القيات القصة التفاعلية كما يلي: من خلال الإطلاع على الدراسات السابقة والبحوث والأدبيات في مجال القصة التفاعلية تم التوصل إلى قائمة مبئية بمهارات إنتاج القصة التفاعلية باستخدام برنامج Story Line، وتم عرض هذه المهارات على (• (1) من المحكمين من تخصص تكنولوجيا التعليم للتأكد من صدقها

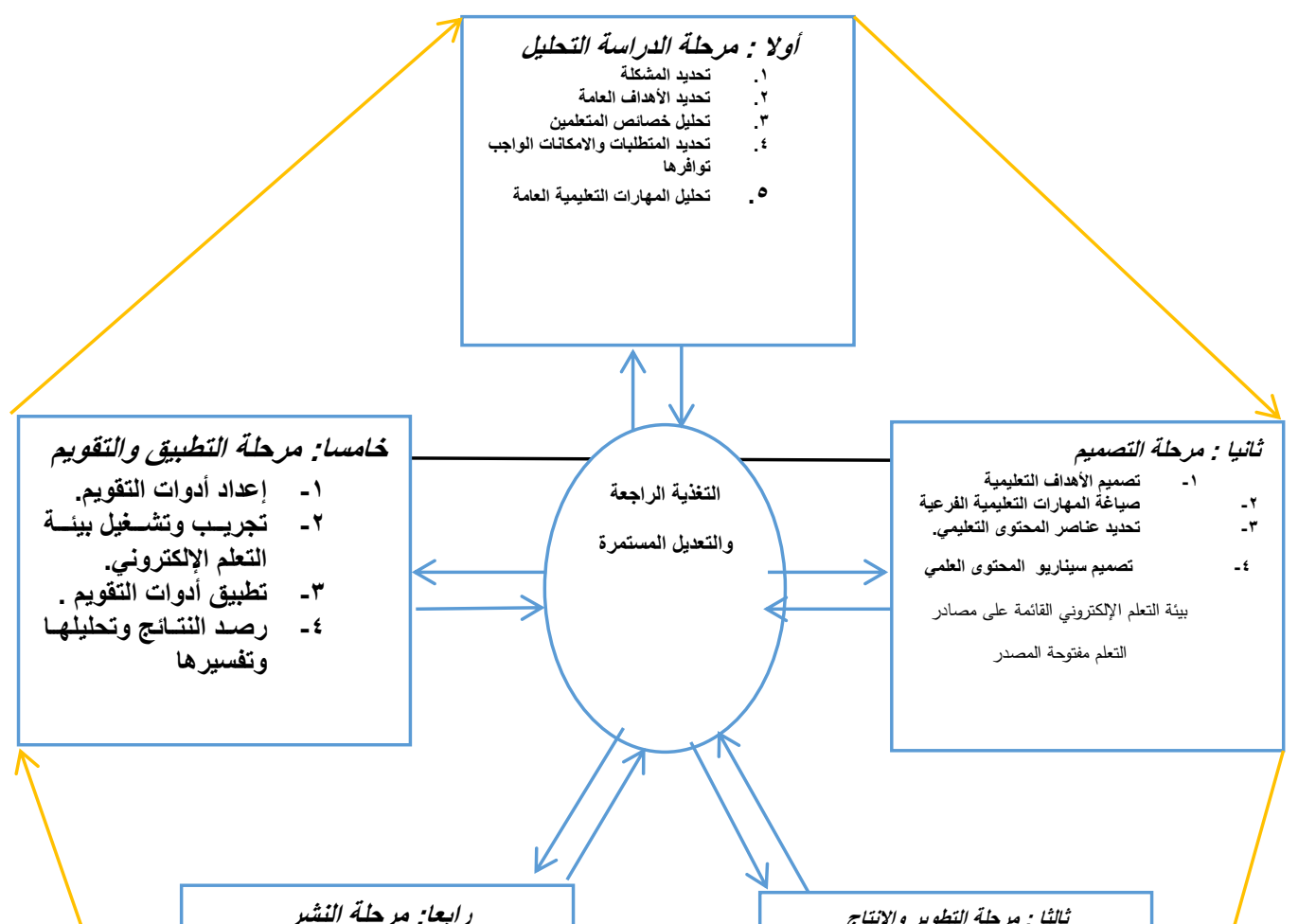


شكل(ץ) نموذج مقترح لتصميم بيئة التعلم الإلكتروني القائعة على مصادر التعلم مفتوحة المصدر

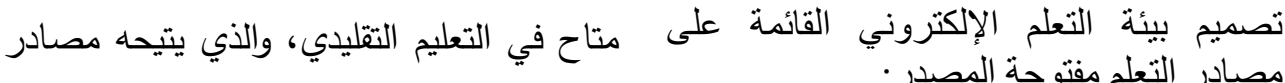
التعلم مفتوحة المصدر من تواصل الطالبات وتعاونهم مع بعضهن البعض. r

تم تحديد الأهداف العامة لبيئة التعلم الإلكتروني القائمة على مصادر التعلم مفتوحة المصدر من خلال دراسة الجانب النظري لإنتاج القصة ملهدة التفاعلية والجانب التطبيقي لهذه المهارات. r- تحليل خصائص المتعلمين: الهدف من التحليل هو التعرف على الطالبات

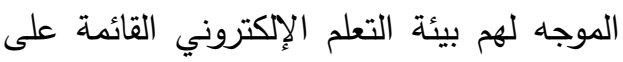
مصادر التعلم مفتوحة المصدر، وهم طالبات الدراسات العليا الدبلوم الخاص تخصص رياض يتكون النموذج المقترح لبناء وتصميم بيئة التعلم الإلكتروني القائمة على مصادر التعلم مفتوحة المصدر من ستة مراحل وهى: أ- مرحلة الاراسة والتحليل وتثتمل على: 1- تحديد المشكلة:

تحدت المشكلة حيث لاحظت الباحثة تخبط وعشوائية لاى الطالبات في انتاج القصة التقاعلية وهذا ما أرجعته الباحثة إلى وجود

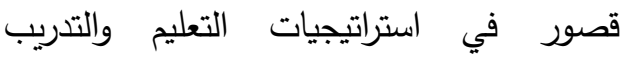
المستخدمة في تتمية مهارات تصمبم وانتاج القصة التفاعلية، وحاجة تصميم القصة التفاعلية إلى المشاركة والتعاون بين الطالبات وهذا غير وهات الهات 


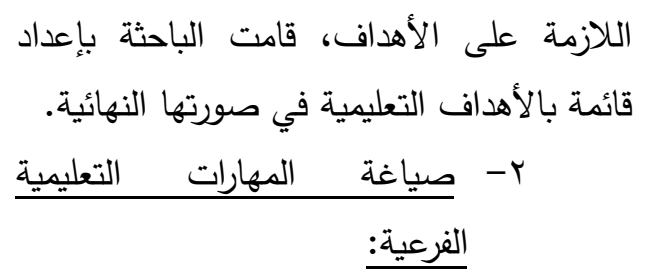

تم تحليل المهارة إلى مهارات رئيسية، وتم تحليل كل مهارة رئيسية إلى مهارات فرعية، وكل مهارة فرعية إلى أداء متسلسل أو خطوات سلوكية بسيطة، ثم قامت الباحثة بإعداد قائمة بالمهارات

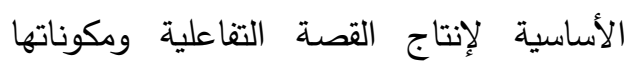
الفرعية في صورتها الأولية، وذلك بهدف عرضها على مجموعة من من المحكمين المتخصصين في مجال تكنولوجيا التعليم، .

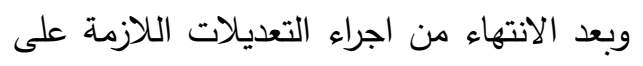
قائمة المهارات، قامت الباحثة بإعداد قائمة بالمهارات العملية في صورتها النهائية حيث لباعهات تكونت من(10) مهارة رئيسية و(·r) مهارة فرعية، و) • V آلداء سلوكي. r- تحديد عناصر المحتوى التعليمي: بعد الإطلاع على الكتب والدراسات السابقة ذات

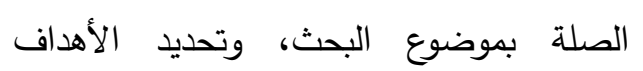

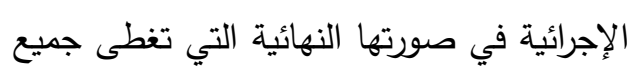
العناصر الأساسية به، تم استخلاص وصياغة

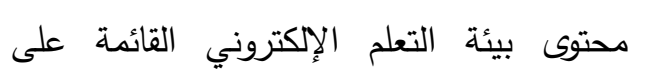
مصادر التعلم مفتوحة المصدر الذي يغطى هذه لإلكروني

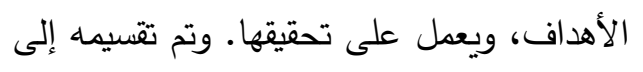

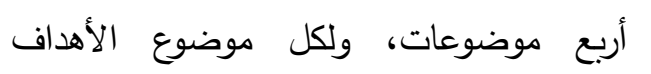
الإجرائية الخاصة باه، والمحتوى التعليمي تم
أطفال، حيث تزيد أعمارهم عن Y T سنة، وهم في مرحلة اتزان، ولديهج رغبة في معرفة الجديد

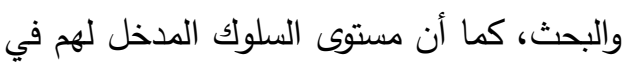
إنتاج القصة التفاعلية متجانس، كما أن طالبات ملتول

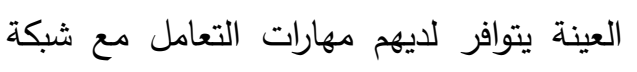

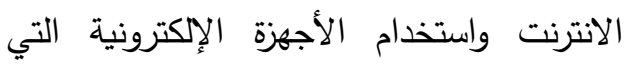
تعمل بنظام ابل أو الأندرويد. ع- تحديد المتطلبات والامكانات الواجب الوند

\section{توافرها:}

تم تحديد المتطلبات والامكانات اللازمة لإنتاج

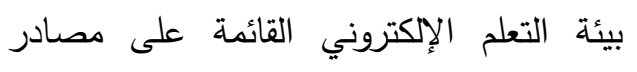

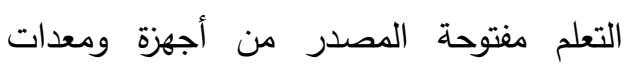
وبرامج. 0- تحليل المهارات التعليمية العامة:

قامت الباحثة بالإطلاع على الكتب والمراجع والدراسات والبحوث في إنتاج القصة التفاعلية باستخدام برنامج Story Line، وقامت بالتعامل

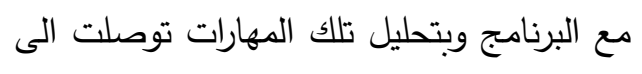
10 مهارة رئيسية لإنتاج القصة التفاعلية. ب- مرحلة التصميم: ا- صياغة الأهداف التصئة الإجرائية:

أعدت الباحثة قائمة مبدئية بالأهداف العامة السابق تحديدها، وتحليلها إلى أهداف فرعية لكل

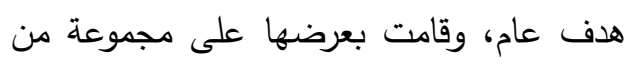
المحكمين، وبعد الانتهاء من إجراء التعديلات المحكمين، وبع الاتهاء من إجراه لتعيلات 
تقسيمه إلى مجموعة من الموضوعات إطارات السيناريو، وتم إجراء التعديلات (الموديولات التعليمية) المرتبطة بالمهارات المطلوبة ليصبح السيناريو في صورته النهائية

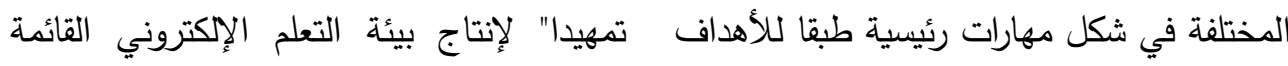
على مصادر التعلم مفتوحة المصدر .

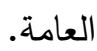
وتم عرضه على مجموعة من المحكمين لمعرفة ج- مرحلة الإنتاج والتطوير: آرائهم، وبعد اجراء التعديلات في ضوضه على أراءا . إنتاج الوسائط المتعددة:

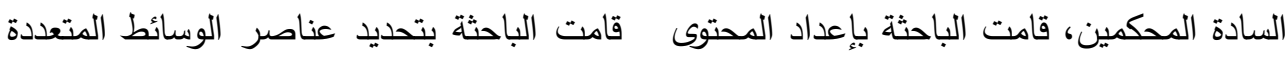

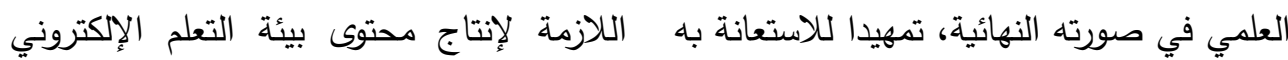

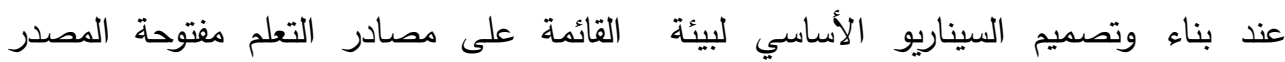

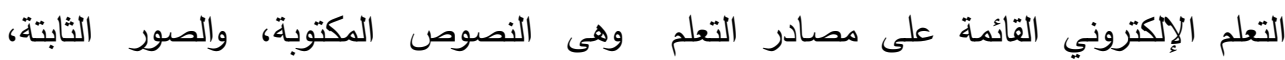

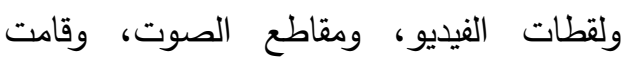
مفتوحة المصدر. ؟- تصميم سيناريو المحتوى العلمي بإنتاج تلك العناصر .

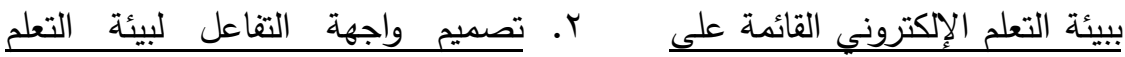

$$
\text { مصادر التعلم مفتوحة المصدر: }
$$

تم إعداد سيناريو لخطوات تتفيذ شاشات محتوى تصميم واجهة تفاعل لبيئة التعلم الإلكتروني

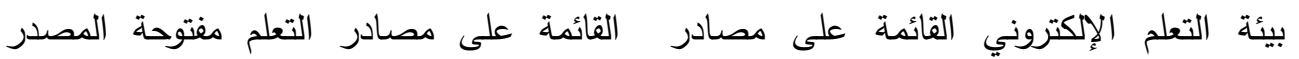
التعلم مفتوحة المصدر وهو عبارة عن إطارات بشكل جيد يجنب المتعلم الوقوع في حيرة أثناء أو لوحات أو شاشات تشتمل على رسم كروكى الاستخدام، ويساعده في التعلم، واستخدام بيئة للثاشة، وخطوات مهارات إنتاج القصة التعلم الإكتروني بكفاءة، حيث أنى أن واجهة

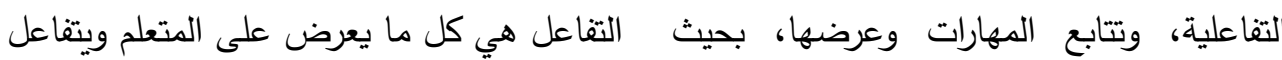
يصبح هذا السيناريو كخطة متكاملة، ، مع معاه، وقد تم تصميم واجهات التفاعل في بيئة مراعاة أسس ومواصفات تصميم بيئة التعلم التعلم الإكتروني القائمة على مصنع مصادر التعلم

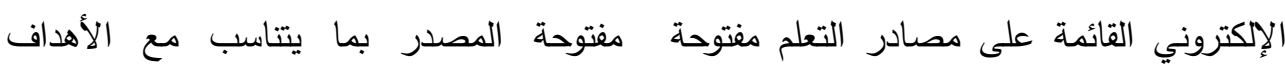
المصدر • التعليمية ومتطلبات التعلم. وبعد تصميم السيناريو، تم عرضه على مجموعة ب. إنشاء بيئة التعلم الإلكتروني القائمة على

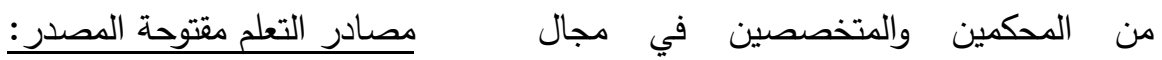
تكنولوجيا التعليم لإبداء الرأي في كل إطار من فين 
قامت الباحثة بالتعاون مع أحد المبرمجين بإنتاج في هذه المرحلة تم اتخاذ جميع الإجراءات

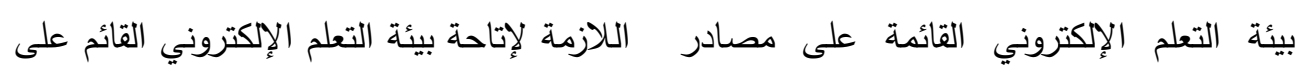

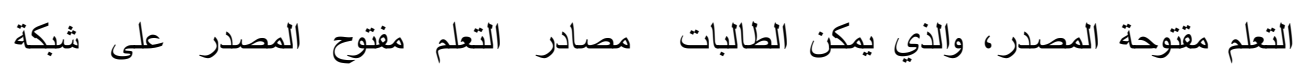

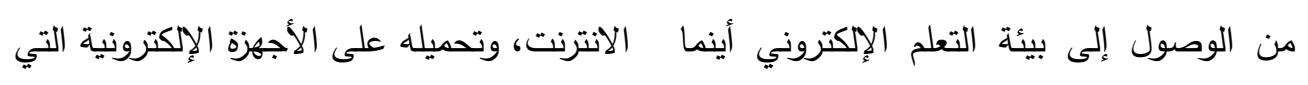

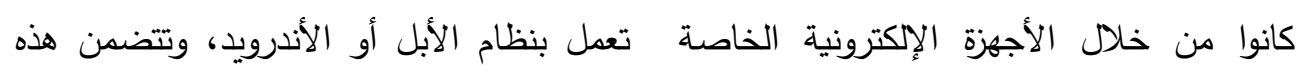

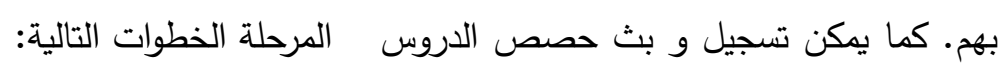
الحية، كما توجد إمكانية الدردشة النصية مع إل ت توفير مساحة تكفى للنشر على الشبكة: الطالبات أثثاء البث الحي، والتواصل المباشر تم حجز مساحة 3GB لاستضافة بيئة التعلم باستخدام الصوت والفيديو، واستخدام أدوات الإكتروني القائم على مصادر التعلم مفتوح السبورة لكتابة أو رسم أي شيء و تحميل الفيل المصدر على سيرفر خارجى، وقد تم التسجيل

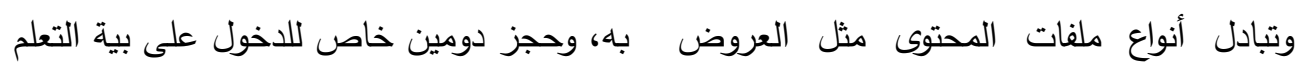
والصور والوثائق و ملفات PDF وجداول الإلكتروني القائمة على مصادر التعلم مفتوحة

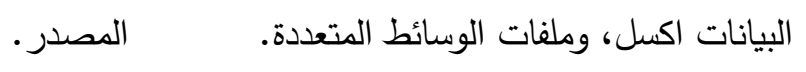

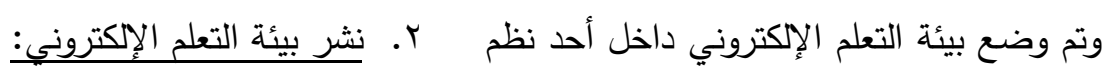

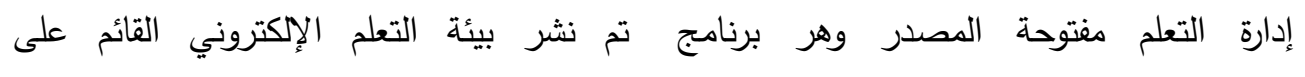

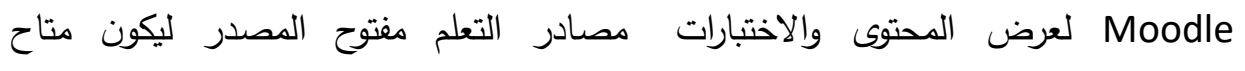

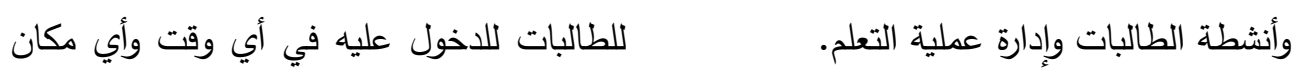

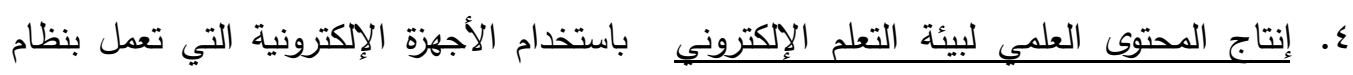

القائمة على مصادر التعلم مقتوحة المصدر: ابل أو الأندرويد. تم إنتاج المحتوى العلمي داخل البيئة باستخدام هـ - مرحلة التقويم البنائى:

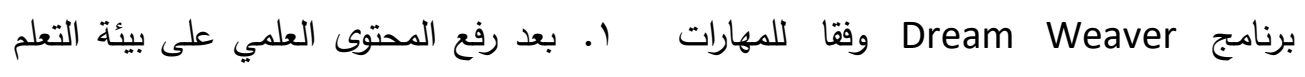

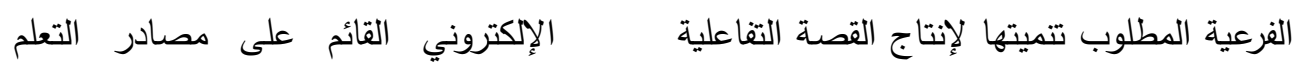

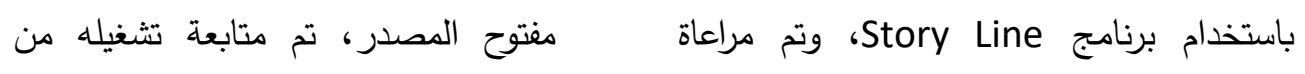

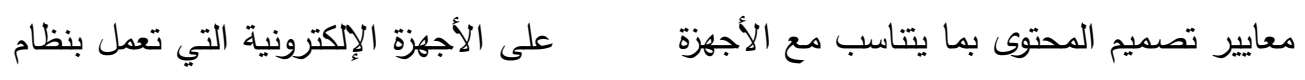

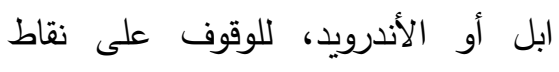
الإلكترونية.

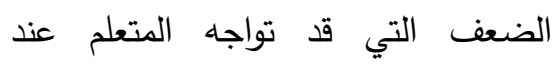
د - مرحلة النشر: الدخول على بيئة التعلم الإكتروني. 


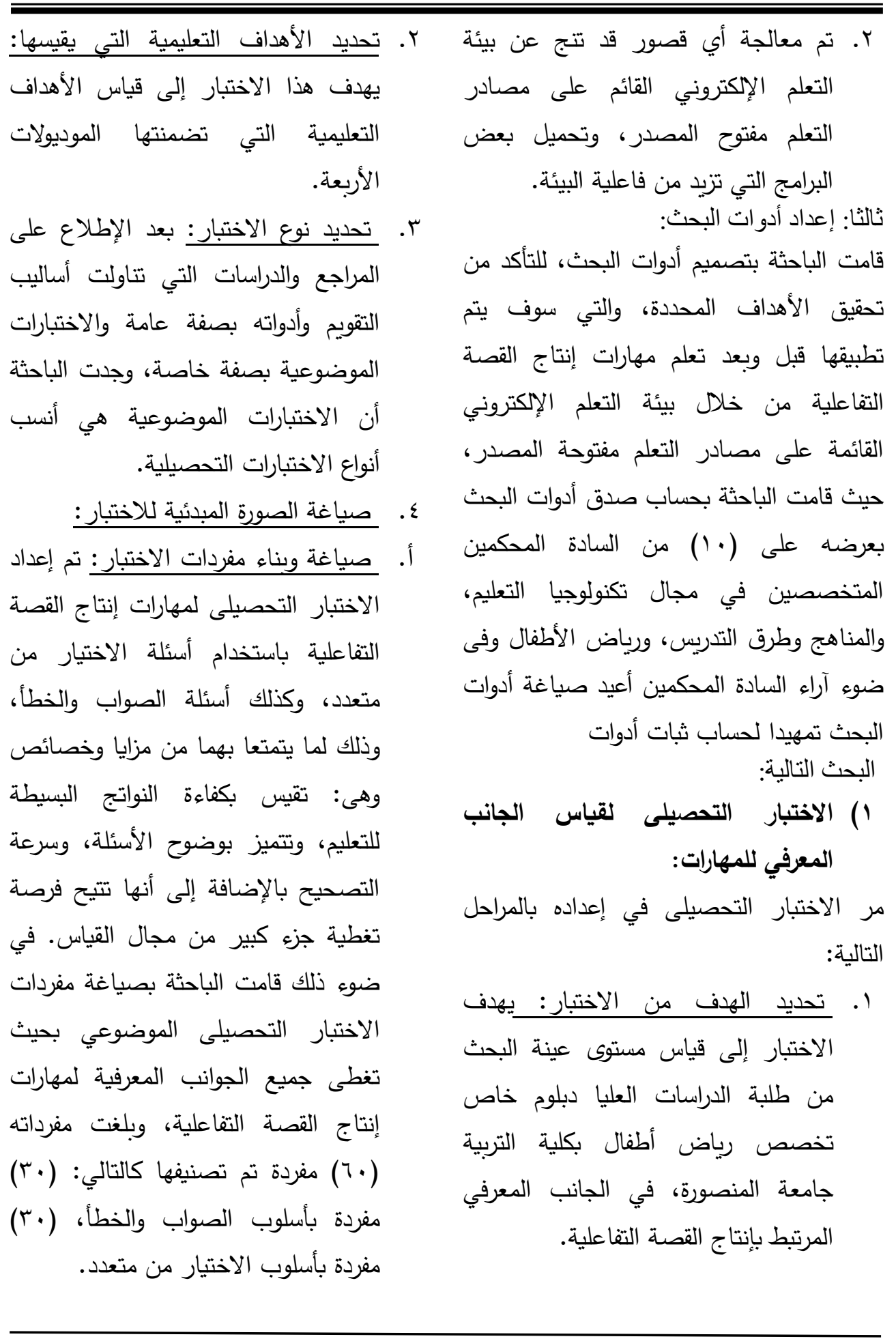




\begin{tabular}{|c|c|}
\hline حساب درجة سهولة وصعوبة مفردات & ب.صياغة تعليمات الاختبار: تم صياغتها \\
\hline الاختبار: تم حساب معامل السهولة & في مقدمة الاختبار وروعي أن تكون \\
\hline والصعوبة لكل مفردة من مفردات & واضحة ودقيقة ومختصرة ومباشرة \\
\hline الاختبار، وقد وجدت الباحثة أن & ومبسطة حتى لا تؤثر على استجابة \\
\hline معاملات السهولة والصعوبة تراوحت & الطالبة وتغير من نتائج الاختبار ، وأن \\
\hline 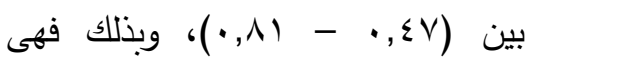 & توضح للطالبة كيفية تدوينها للاجابه لكل \\
\hline ليست شديدة السهولة وليست شديدة & سؤال، وكيفية الخروج الآمن بعد الانتهاء \\
\hline الصعوبة، وبالتالى فإن أسئلة الاختبار & 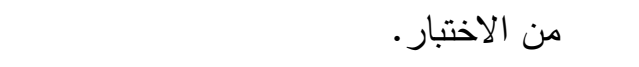 \\
\hline تتمتع بقيم مناسبة لمعاملات السهولة & ج. تقدير الدرجة وطربقة التصحيح: تم \\
\hline والصعوبة. & وضع درجة لكل مفردة من مفردات \\
\hline 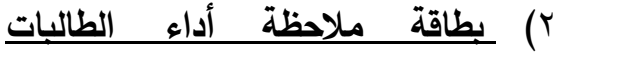 & الاختبار وبالتالي كان مجموع درجات \\
\hline لمهارات إنتاج القصة التفاعلية: & الاختبار التحصيلى(· ؟). \\
\hline تم إعداد بطاقة الملاحظة وفقا للخطوات & 0. إعداد جدول المواصفات للاختبار \\
\hline 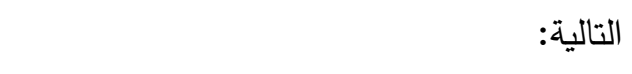 & التحصيلى: \\
\hline ا. تحديد الهدف من بناء بطاقة & قامت الباحثة بإعداد جدول المواصفات للاختبار \\
\hline الملاحظة: استهدفت هذه البطاقة & التحصيلى في ضوء الأهداف العامة للموديلات \\
\hline قياس مستوى أداء طالبات الدبلوم & الأربعة، بهدف التحقق من عدد الأسئلة لكل \\
\hline الخاص تخصص رياض أطفال بكلية & هدف من الأهداف المراد تحقيقها. \\
\hline التربية جامعة المنصورة لمهارات إنتاج & T. الصورة النهائية للاختبار التحصيلى: \\
\hline القصة التفاعلية قبل وبعد الدخول & التجربة الاستطلاعية للاختبار التحصيلى: \\
\hline على بيئة التعلم الإككتروني القائمة & قامت الباحثة بإجراء التجربة الاستطلاعية \\
\hline على مصادر التعلم مفتوحة المصدر . & للاختبار ، وذلك بهدف تحقيق الأهداف التالية: \\
\hline r. تحديد الأداءات التي تتضمنها بطاقة & أ. تحديد الزمن اللازم للإجابة على \\
\hline الملاحظة: تم تحديد الأداءات من & الاختبار: قامت الباحثة برصد الزمن \\
\hline خلال الاعتماد على الصورة النهائية & الذي استغرقه أسرع طالب والزمن إلى \\
\hline لقائمة مهارات إنتاج القصة التفاعلية & استغرقه أبطأ طالب، وعلى ذلك أمكن \\
\hline التي تم التوصل إليها، حيث صيغت & للباحثة حساب الزمن المناسب للاختبار \\
\hline
\end{tabular}




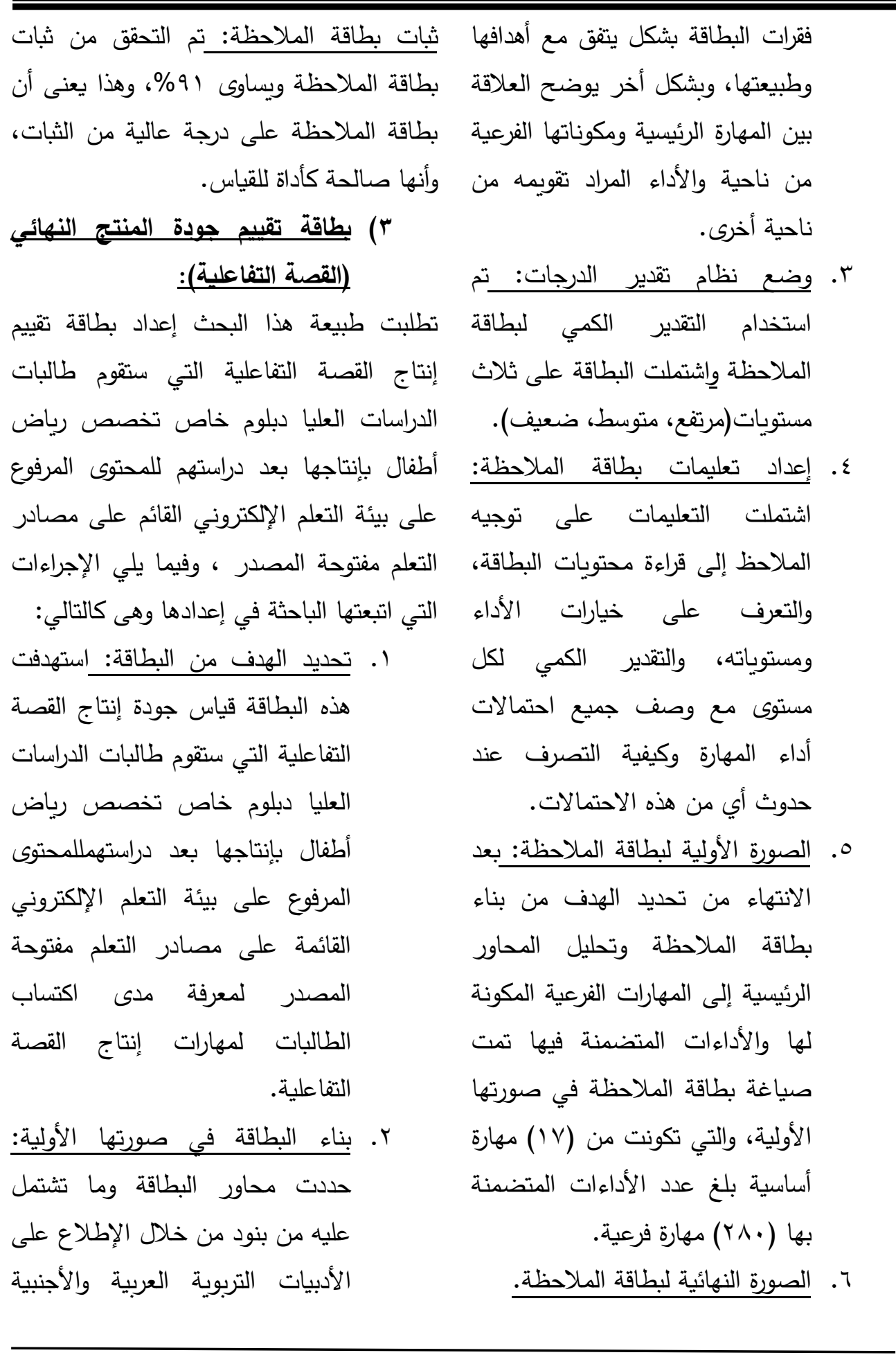




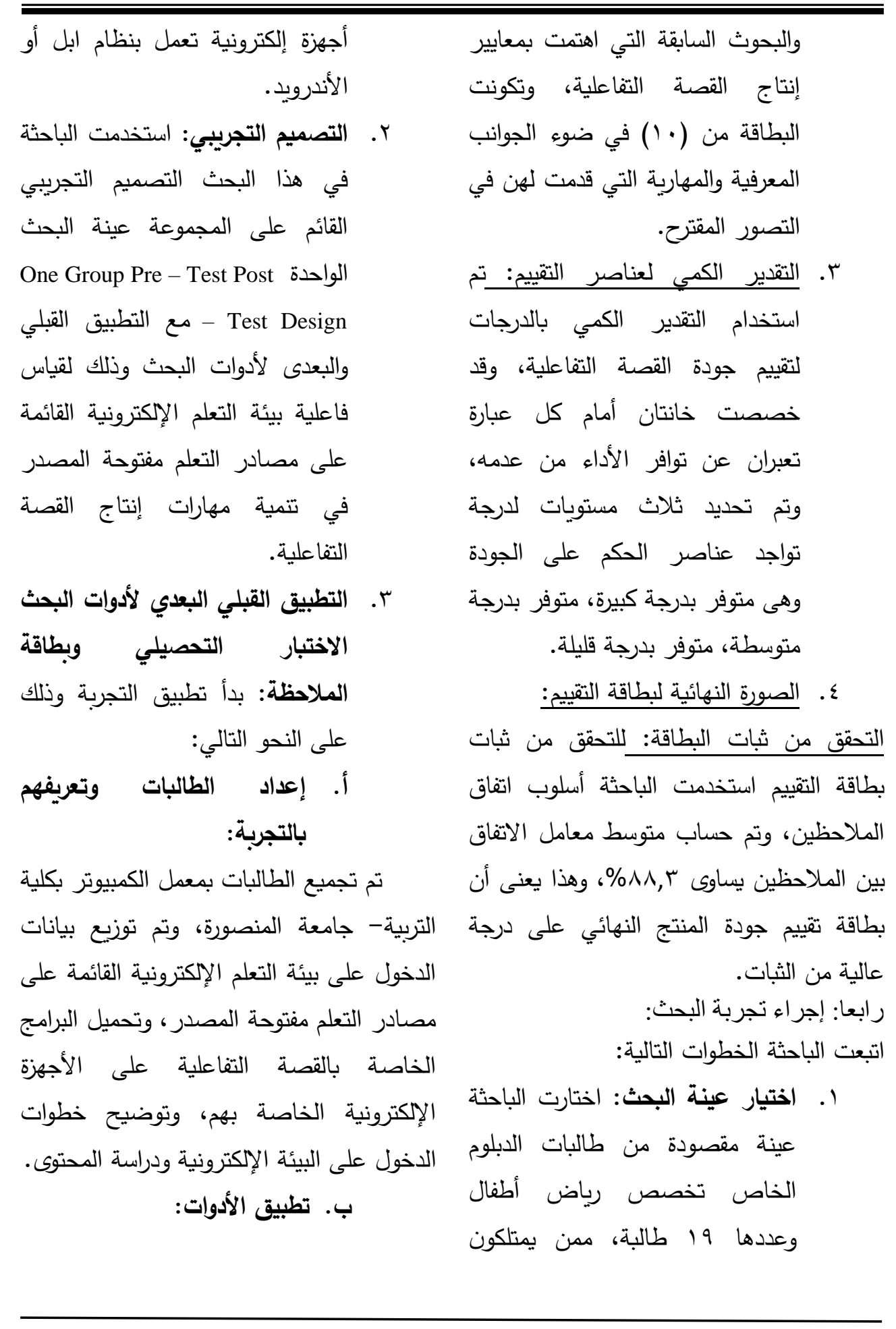


التحصيلى المعرفي ورصد درجات

الطالبات، وتطبيق بطاقة الملاحظة

البعدية لمهارات إنتاج القصة التقاعلية

باستخدام برنامج Story Line على

الطالبات، ثم تطبيق بطاقة تقييی

المنتج النهائي للقصة التفاعلية التي لتصلي

أنتجتها الطالبات، ورصد كل الدرجات

في كثوف خاصة تمهيدا لإجراء

المعالجات الإحصائية وعرض نتائج

البحث، ومناقشتها، وتفسيرها.

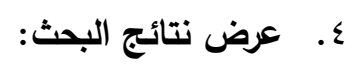

بالنسبة للفرض الأول ونصية: " يوجد فرق ذو نائ

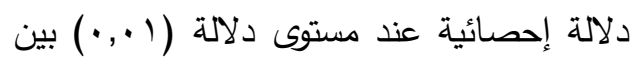

متوسطي رتب درجات طالبات المجموعة عينة

البحث في التطبيق القبلي والتطبيق البعدي في دئ دات

التحصيل المرتبط بالجانب المعرفي لمهارات

إنتاج القصة التفاعلية لصالح التطبيق البعدي" لاتبل

ولاختبار هذا الفرض استخدمت الباحثة معادلة

ويلكوكسن Wilcoxon لتحديد دلالة الفروق

بين متوسطي رتب درجات الطالبات في دلات لئل

القياسيين القبلي، والبعدي للاختبار التحصيلى رثي دئي

للمجموعة عينة البحث التي درست من خلال

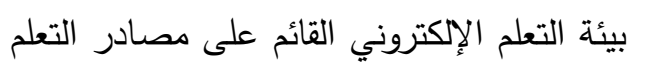

مفتوحة المصدر وكانت النتائج كما في الجدول

$$
\text { الآتي: مفتوح: }
$$

قامت الطالبات بالاخول على الاختبار

التحصيلى على بيئة التعلم الإلكترونية القائمة على مصادر التعلم مفتوحة المصدر والإجابة عليه، واتبعوا التعليمات الخاصة به في الوقت المحدد له، وبعد الانتهاء من الإجابة على لهاته الاختبار بدأت الباحثة بملاحظة أداء الطالبات الإهاء

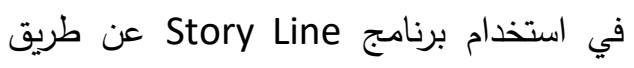
بطاقة الملاحظة المخصصة لذلك.

\section{ج. تجريب بيئة التعلم الإكترونية القائمة}

\section{على مصادر التعلم مفتوحة المصدر:}

تم تعريض الطالبات لبيئة التعلم الإكتروني معوحهـ

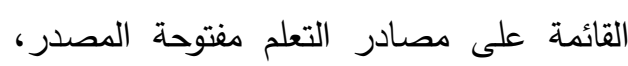
لدراسة المحتوى من خلال استخدام البيئة

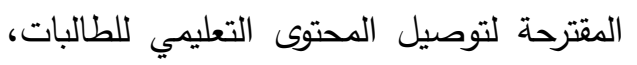

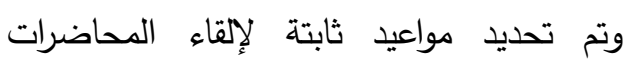
المتزامنة، ثم تسجيلها في مصادر التعلم مفتوحة

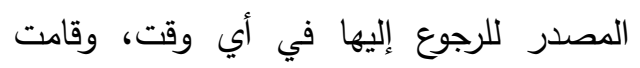

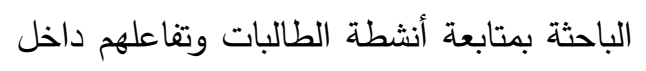
البيئة الإكترونية، واستعراض التقارير الخاصة التئه بنشاط كل طالبة، وتحديد عدد الساعات أربع ساعات في الأسبوع لمدة شهر التي تم التعامل فيها مع البيئة الإكترونية. د. التطبيق البعدى للأدوات: بعد الانتهاء

من التعرض للبيئة التعلم الإكترونية القائم على مصنادر التعلم مفتوحة المصدر طبقت أدوات البحث الثلاث بعديا، حيث تم الدخول على الاختبار 
جدول (1): قيمة (Z) ودلالتها الإحصائية للفروق بين القياسيين القبلي والبعدي للمجموعة التجريبية

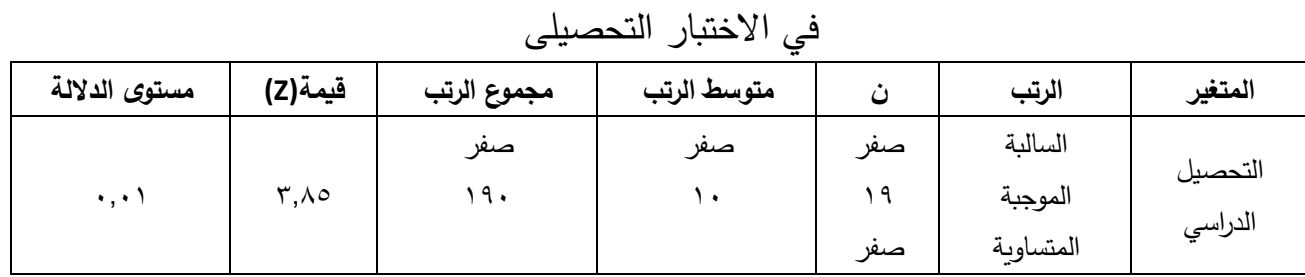

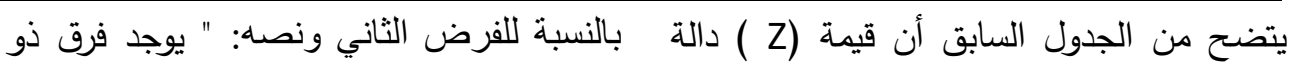

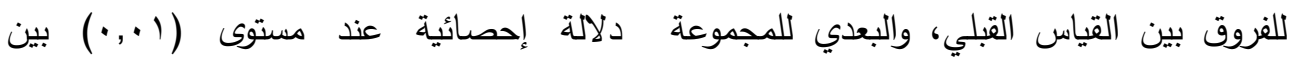
التجريبية في الاختبار التحصيلى، لصالح متوسطي رتب درجات طالبات المجموعة عينة

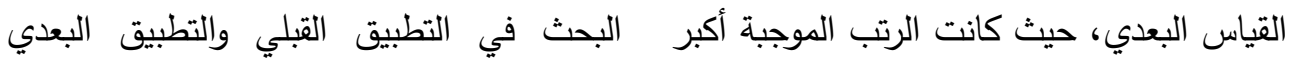
من الرتب السالبة، مما يثير إلى وجود فرق ذو لألداء مهارات بطاقة الملاحظة الخاصة بالجانب دلالة إحصائية بين متوسطي رتب درجات الأدائي لمهارات إنتاج القصة التفاعلية لصالح

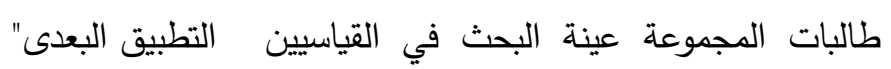
القبلي والبعدي على الاختبار التحصيلى في ولاختبار هذا الفرض استخدمت الباحثة معادلة الجوانب المعرفية اللازمة لإنتاج القصة ويلكوكس فilcoxon لتحديد دلالة الفروق التفاعلية، وذلك لصالح القياس البعدي، وهذه بين متوسطي رتب درجات طالبات المجموعة

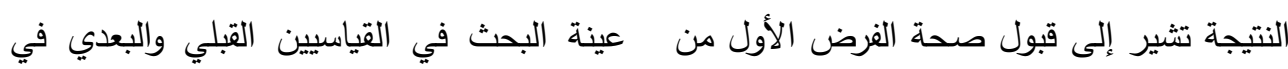

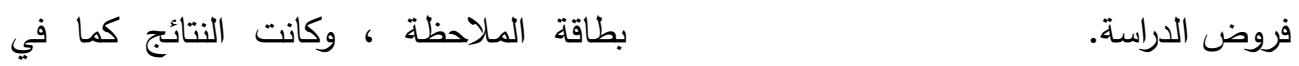

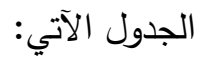

جدول (Y): قيمة(Z) ودلالتها الإحصائية لرتب الفروق بين القياسيين القبلي والبعدي لطالبات المجموعة عينة البحث في بطاقة الملاحظة

\begin{tabular}{|c|c|c|c|c|c|c|}
\hline مستوى الدلالة & قيمة(Z) & مجموع الرتب & متوسط الرتب & ن & الرتب & المتفير \\
\hline$\cdot, \cdot 1$ & $r, \wedge r$ & صفر 19. & صفر & صفر 19 & المتالبة المساوبة & الملاحظة \\
\hline
\end{tabular}

يتضح من الجدول السابق أن قيمة Z دالة الرتب السالبة مما يشير إلى وجود فرق ذو دلالة

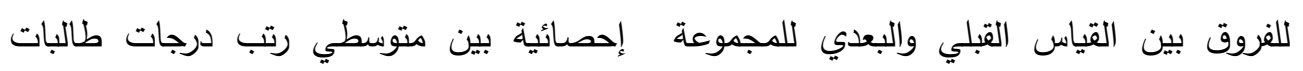
التجريبية في بطاقة الملاحظة لصالح القياس المجموعة عينة البحث في القياسيين القبلي البعدي، حيث كانت الرتب الموجبة أكبر من والبعدي لبطاقة الملاحظة في أداء مهارات إنتاج 


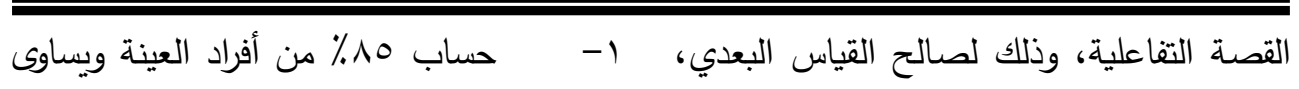
وهذه النتيجة تشير إلى قبول صحة الفرض 17 إلى طالبة.

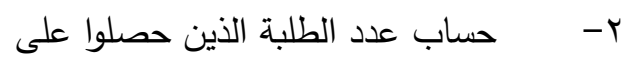
الثاني من فروض الدراسة.

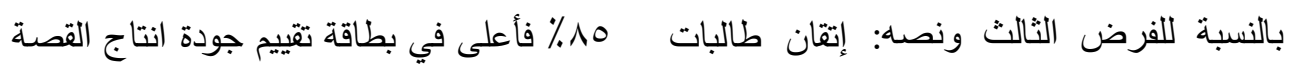

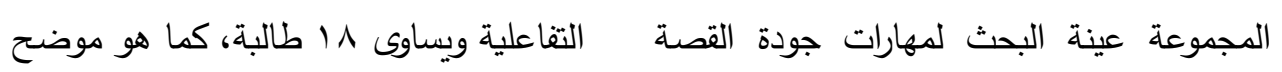
في الجدول التالي.

التفاعلية بمستوى الإتقان المطلوب (0^\%)")

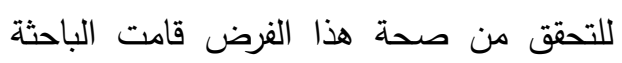
بما يلي:

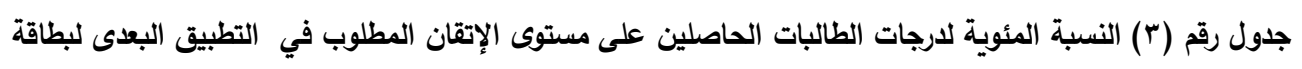

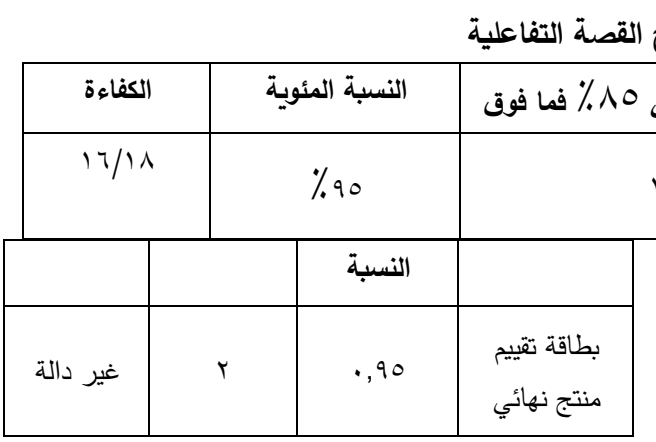

يلاحظ من الجدول السابق عدم وجود فرق ذو

دلالة إحصائية بين متوسط النسبة المئوية لارجات الطالبات في بطاقة تقييم المنتج النهائي

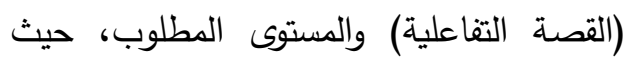
كانت قيمة z المحسوبة أقل من قيمة z الحرجة وبذلك تم قبول الفرضية الصفرية مما يعنى أن بيئة التعلم الإلكتروني القائم على مصادر التعلم مفتوحة المصدر لها فاعلية في إتقان الطالبات التعلي لمهارات القصة التقاعلية وإنتاجها بدقة. تفسير نتائج البحث من النتائج السابقة يتضح أنه يوجد فاعلية لبيئة التعلم الإلكتروني القائمة على مصادر التعلم

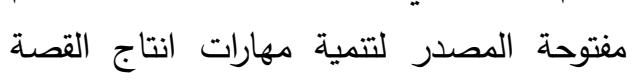
تقييم جودة انتاج 
التفاعلية وقد استفادت الباحثة من الدراسات طالبات المجموعة عينة البحث في التطبيق البقاء

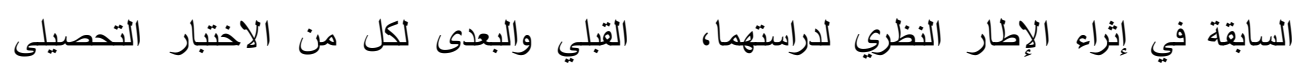

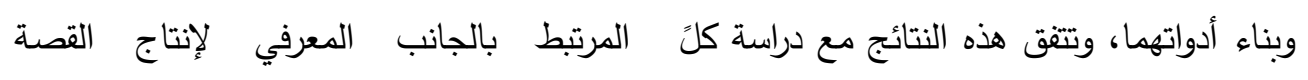

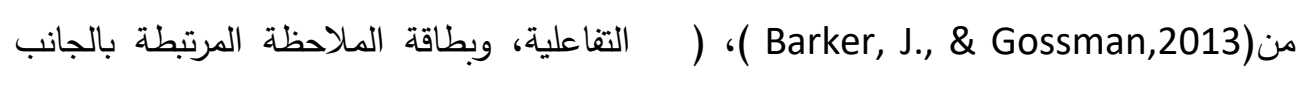
الأدائي لمهارات إنتاج القصة التفاعلية، وبطاقة تقيم جودة المنتج النهائي (القصة التفاعلية)

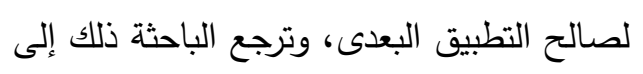

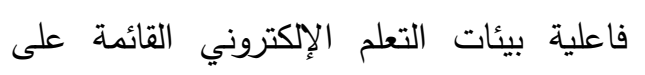

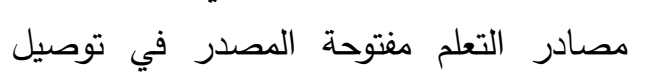

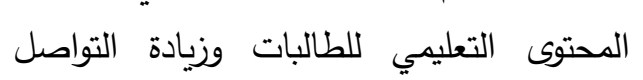
والتفاعل والتثارك بين الطالبات في التياج القصة التفاعلية.

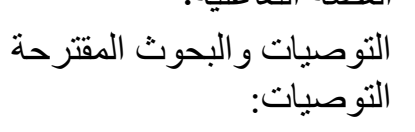

في ضوء نتائج البحث توصى الباحثتان بالآتي:

ا ـ. مسايرة الاتجاهات الحديثة واستخدام الأساليب الجديدة التي تؤدى إلى رفع مستوى عمليتي التعليم والتعلم. r. توجيه نظر القائمين على إعداد المناهج

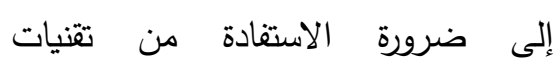
التكنولوجيا الحديثة المرتبطة بمصادر التعلم مفتوحة المصدر . r. استخدام البيئات الإلكترونية في التعليم بثكل أكثر فاعلية لأهميتها وفاعليتها في الإنيروني التعليم. بتُكل ـ. الاهتمام ببيئات التعلم الإكتروني وتحويل القصص في صورة إلكترونية تفاعلية (G,2014) والتي أشارت نتائجها إلى أن البيئات التعليمية الإكترونية تساعد المتعلمين علي زيادة دافعيتهم نحو التعلم مع العمل علي تعزيز

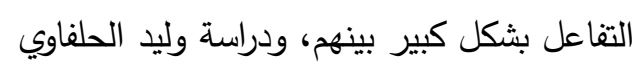

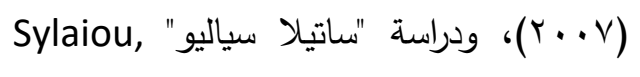

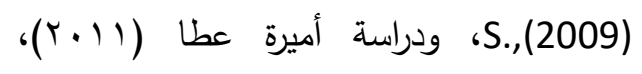

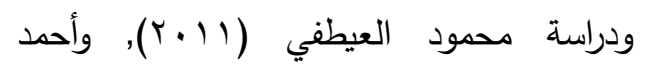

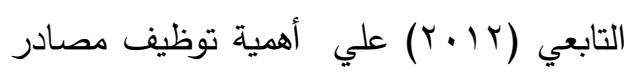

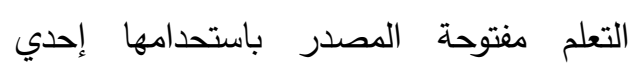
شبكات التواصل الإجتماعي(الفيس بوك) كأحد

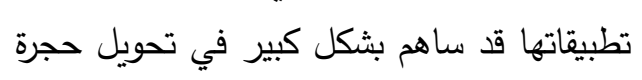

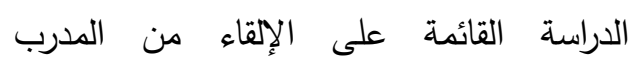
والاستماع من المتدرب إلى بيئة تدريبية تمتاز

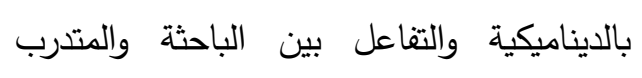
وزملائه سواء عن طريق غرفة الثات أو من

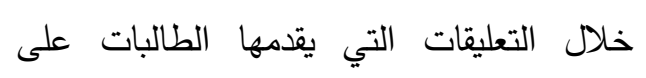

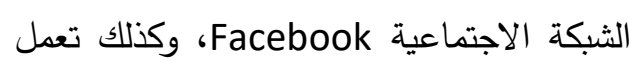
علي تثجيع التعلم المستقل وتوفير المرونة في التعلم، وأن هنالك فائدة كبيرة للطالبات والمعلمين

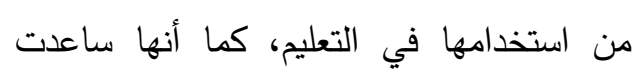
علي رفع دافعيتهم نحو التعلم هذا وقد أشارت نتائج البحث الحالي إلى وجود التعات

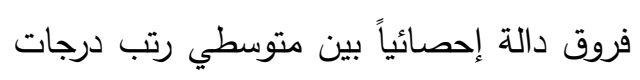




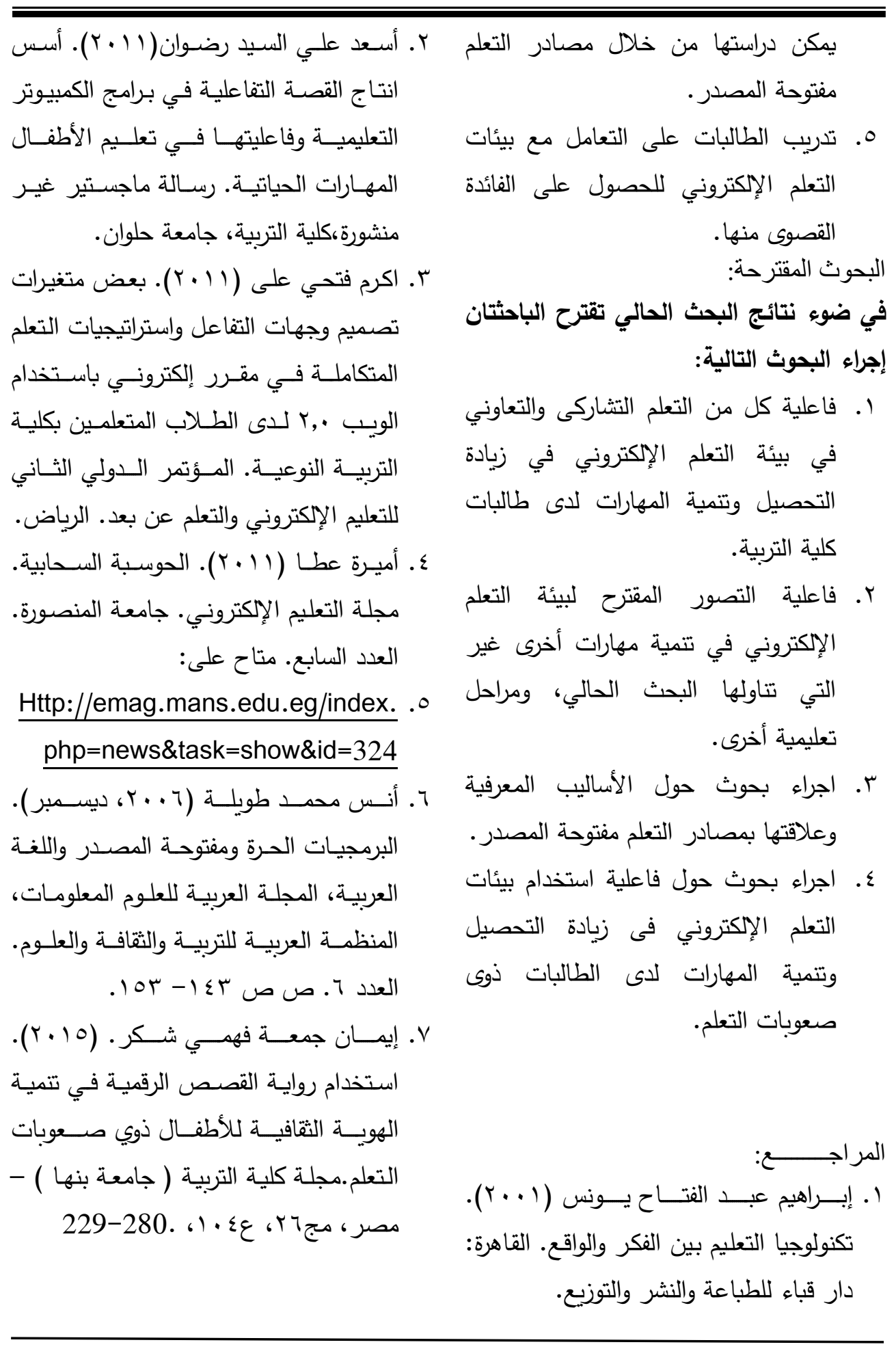




$$
\begin{aligned}
& \text { 1. حسن الباتع محمد عبد العاطي، السيد عبدالإلكترونـي (الاســتراتيجيات- الأدوات- }
\end{aligned}
$$

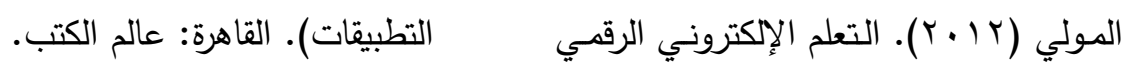

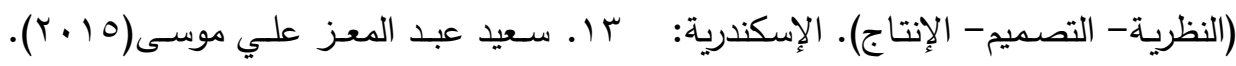

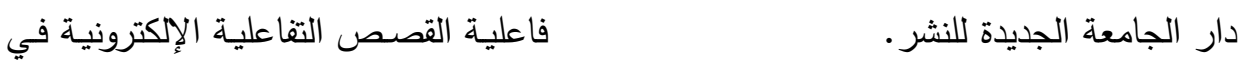

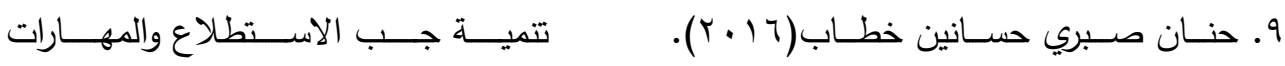

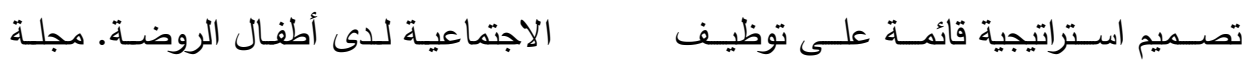

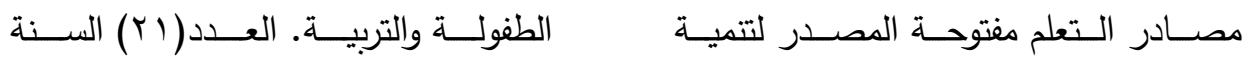

$$
\begin{aligned}
& \text { مهارات إنتاج المتـاحف الإفتراضـية لـدى السابعة. }
\end{aligned}
$$

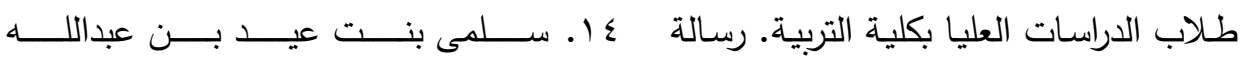

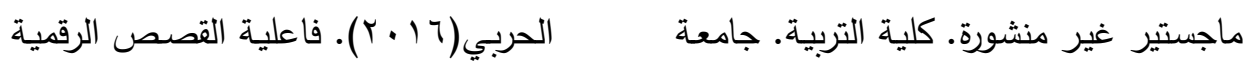

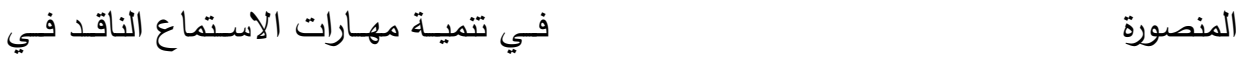

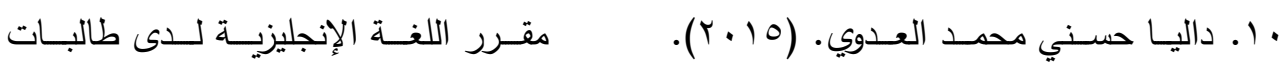

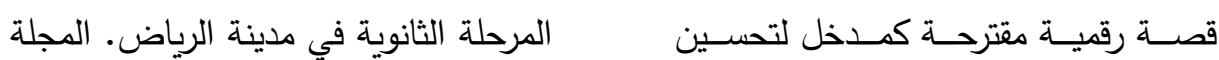

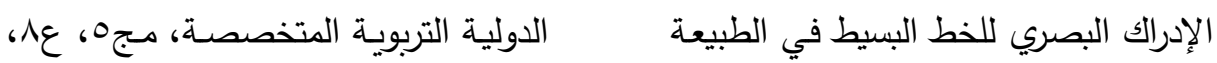

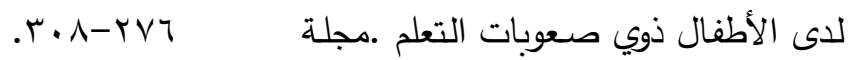

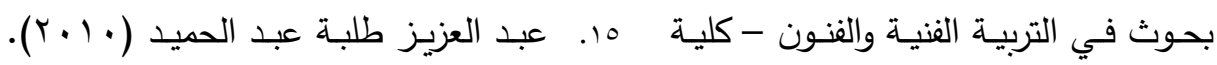

$$
\begin{aligned}
& \text { التربيـة الفنيـة - جامعـة حلوان - مصـر ، سلسـلة اسـتراتيجيات الـتعلم الإلكترونسي. }
\end{aligned}
$$

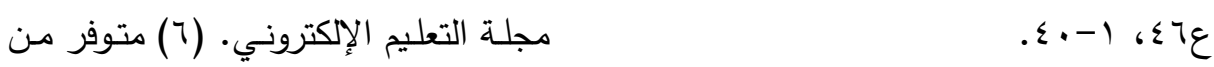

$$
\begin{aligned}
& \text { خ } \\
& \text { http://emag.mans.edu.eg/index.php?page }
\end{aligned}
$$

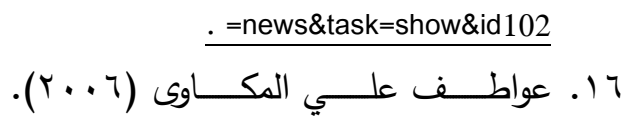

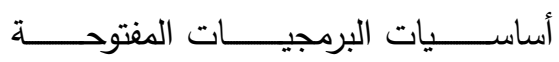

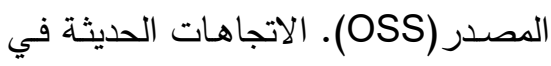

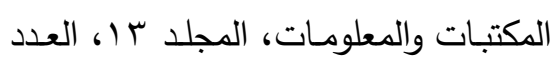

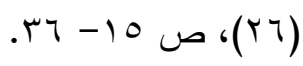

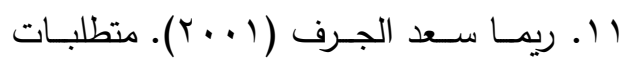

$$
\begin{aligned}
& \text { الانتقـال مـن التعليم التقليدي الـي التعليم }
\end{aligned}
$$

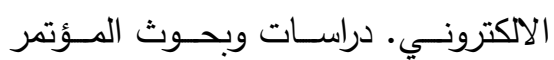

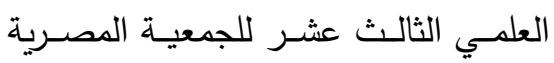

$$
\begin{aligned}
& \text { للمنــاهج وطـرق التـدريس. جامعـة عـين } \\
& \text { شمس. القاهرة. } \\
& \text { r ا. ريهـــام الغـــول، أمــين صـــلاح الــدين }
\end{aligned}
$$

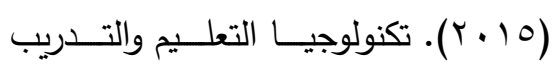




\begin{tabular}{|c|c|}
\hline اللغة العربية للى متعلميها غير الناطقين & 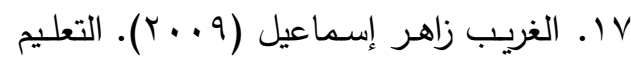 \\
\hline بهـا .الثقافــة والتتميــة -مصــر، سل ال، & الإلكترونـي مـن التطبيـق إلـي الإحتـراف \\
\hline ع & والجودة. القاهرة: عالم الكتب. \\
\hline ـ ؟. ميســون عــادل منصــور محمـود صــالح & 1 ا ـ محمد سعيد العمودي (V . . ץ). تقييم واقع \\
\hline 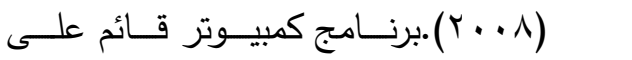 & تـدريب الحاسـب في كليـة التربيـة جامعـة \\
\hline محاكاة القصة التفاعلية لتتمية بعض القيم & عدن. مجلة العلوم الاجتماعية والإنسانية، \\
\hline الأخلاقية لأطفال ما قبل المدرسة. (رسالة & العدد (Y))، المجلد العاشر . \\
\hline ماجستير غيـر منشـورة). كليـة التربيـة. & 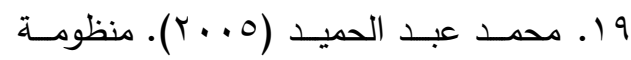 \\
\hline جامعة المنصورة. & التعلـيم عبــر الثــبكات، القــاهرة: عــالم \\
\hline هY. ميسـون عــادل منصـور محمـود صــالح & 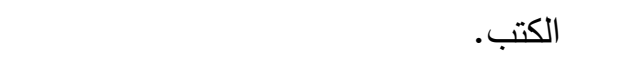 \\
\hline 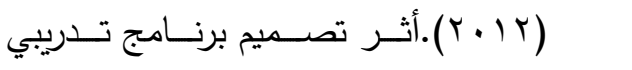 & •r. محمــد عطيــة خمـيس (r... - ج). \\
\hline لنموذج إلكتروني قائم على معايير الإدارة & منتوجات تكنولوجيا التعليم. القاهرة: مكتبة \\
\hline الإلكترونيــة لتطــوير نظـام قبــول وإعـداد & دار الكلمة. \\
\hline الطالبـات بكليـة ريـاض الأطفــال جامعــة & 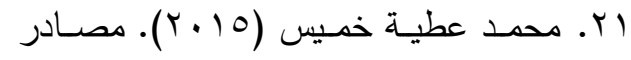 \\
\hline المنصـــورة علــى تحصــيل واتجاهـــات & الــتعلم الإلكتروني.الجـزيء الأول: الأفـراد \\
\hline الطالبــات نحــوه. (رســالة دكتــوراه غيـر & والوســائطـ. القـاهرة: مكتبــة دار الســـاب \\
\hline منشورة). كلية التربية. جامعة المنصورة. & 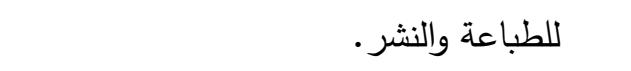 \\
\hline דr. نبيل جاد عزمى (ع ( • Y). بيئات التعلم & 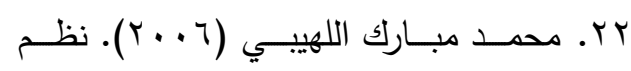 \\
\hline التفاعلية. القاهرة: دار الفكر العربى للنشر & تثـغيل وإدارة الدكتبـات الرقميـة المفتوحـة \\
\hline 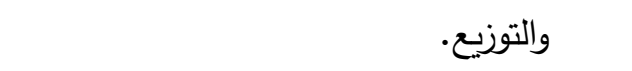 & المصـــــر : نظـــــام دي ســـيبس لإدارة \\
\hline 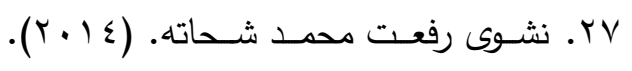 & المجموعـات الرقميــة. مجلــة المكتبــات \\
\hline تصـميم اسـتراتيجية تعليميـة مقترحسة عبـر & والمعلومــات العربيـة، العـدد الثـاني، ص ص \\
\hline الويب في ضوء نموذج أبعاد التعلم لتتمية & ص ص 91Y- .10. \\
\hline مهارات تطوير القصص الرقمية التعليمية & 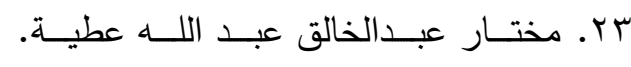 \\
\hline والاتجاه نحوها .تكنولوجيا التعليم -مصر ، & 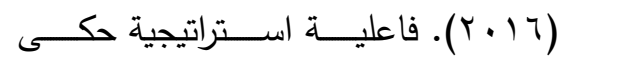 \\
\hline 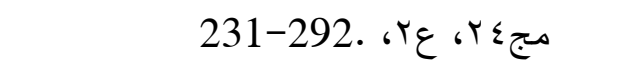 & القصــص الرقميـة التثـــاركية فـي تتميــة \\
\hline & مهارات الفهم الاستماعي والدافعيـة لتعلم \\
\hline
\end{tabular}


WWW.sciencedirect.com Data at access:12-11-2014

35. Hylen, J. (2007). Open educational Resources: Opportunities and Challenges e- School News online, No 5, PP 1-4.2

36. Istenic Starčič, A., Cotic, M., Solomonides, I., \& Volk, M. (2016). Engaging preservice primary and preprimary school teachers in digital storytelling for the teaching and learning of mathematics. British Journal of Educational

37. Technology, 47(1), 29-50.

38. Lakhan, Shaheen E., and Kavita Jhunjhunwala.(2008). " Open Source Software in Education." EDUCAUSE Quarterly $\quad 31 \quad$ (2). http://www.education.edu/ero/article/op en-source-software-education.

39. Mascarell, M. D. M., \& Cabedo, J. L. G. (2014). Entorno virtual de aprendizaje y resultados académicos: evidencia empírica para la enseñanza de la Contabilidad de Gestión. Revista de Contabilidad, 17(2), 108-115.

40. Penttilä, J., Kallunki, V., Niemi, H. M., \& Multisilta, J. (2016). A Structured Inquiry into a Digital Story: Students Report the Making of a Superball. International Journal of Mobile and Blended Learning (IJMBL), 8(3), 19-34.

41. Rahimi, M., \& Yadollahi, S. (2017). Effects of offline vs. online digital storytelling on the development of EFL learners' literacy skills. Cogent Education, 4(1), 1285531

42. Swan, K (2004). Relationships Between Interactions and Learning in Online Environments, Sloan-C Editor for Effective Practices in Learning Effectiveness.

43. Yueqing, Y.\& Lei, F. (2011). Trends of Open Educational Resources in Higher education, Hong Kong.Springer Berlin Hieldberg, PP146-156

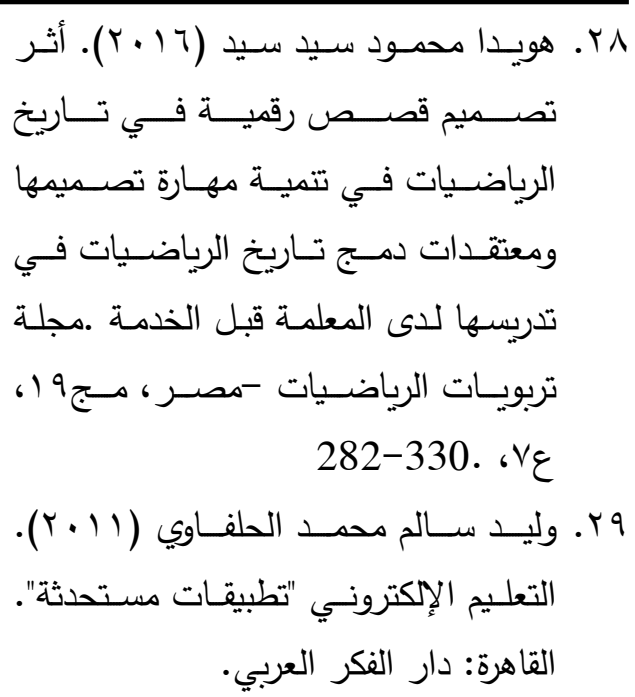

30. Anderson, T. \& Fathi, E. (2004). Theory and Practice of Online Learning. Retrieved. from http://cde.athabascau.ca/online_book.

31. Barker, J., \& Gossman, P. (2013). The learning impact of a virtual learning environment: students' views. Teacher Advancement Network Journal, 5(2).

32. Caplow, Julie (2006). "Where do I put my course materials?", Quarterly Review of Distance Education, Vol.7, No.2.

33. . Daniel, J. (2012, May). Quds Open University of the most important success stories in open learning resources worldwide. Conference on open learning resources held by the International Organization for Education, Science and Culture "UNECO" in co- operation with the Council of Scientific Research, Oman, Muscat.

34. Hernamdes, S (2009) Designing learning environments, improving social interactions: essential variabees for a virtual training space. procedia social and behavioral science 1,2411 - 2415 Retrieved from 
